GLOBAL PATENTS 



\section{Global Patents}

LIMITS OF TRANSNATIONAL ENFORCEMENT

Marketa Trimble 


\section{OXFORD}

\section{UNIVERSITY PRESS}

Oxford University Press, Inc., publishes works that further Oxford University's objective of excellence in research, scholarship, and education.

Oxford New York

Auckland Cape Town Dar es Salaam Hong Kong Karachi Kuala Lumpur Madrid Melbourne Mexico City Nairobi New Delhi Shanghai Taipei Toronto

With offices in

Argentina Austria Brazil Chile Czech Republic France Greece Guatemala Hungary Italy Japan Poland Portugal Singapore South Korea Switzerland Thailand Turkey Ukraine Vietnam

Copyright (C) 2012 by Oxford University Press, Inc.

Published by Oxford University Press, Inc. 198 Madison Avenue, New York, New York 10016

Oxford is a registered trademark of Oxford University Press

Oxford University Press is a registered trademark of Oxford University Press, Inc.

All rights reserved. No part of this publication may be reproduced, stored in a retrieval system, or transmitted, in any form or by any means, electronic, mechanical, photocopying, recording, or otherwise, without the prior permission of Oxford University Press, Inc.

\section{Library of Congress Cataloging-in-Publication Data}

Trimble, Marketa.

Global patents : limits of transnational enforcement / Marketa Trimble.

p. cm.

Includes bibliographical references and index.

ISBN 978-0-19-984068-7 (hardback)

I. Patent laws and legislation. 2. Intellectual property. I. Title.

$\mathrm{K}_{1505 . \mathrm{T}_{75} 2012}$

$346.04^{\prime} 86-\mathrm{dc2} 3$

\section{$\begin{array}{lllllllll}\text { I } & 2 & 3 & 4 & 5 & 6 & 7 & 8 & 9\end{array}$}

Printed in the United States of America on acid-free paper

\section{Note to Readers}

This publication is designed to provide accurate and authoritative information in regard to the subject matter covered. It is based upon sources believed to be accurate and reliable and is intended to be current as of the time it was written. It is sold with the understanding that the publisher is not engaged in rendering legal, accounting, or other professional services. If legal advice or other expert assistance is required, the services of a competent professional person should be sought. Also, to confirm that the information has not been affected or changed by recent developments, traditional legal research techniques should be used, including checking primary sources where appropriate.

(Based on the Declaration of Principles jointly adopted by a Committee of the American Bar Association and a Committee of Publishers and Associations.)

You may order this or any other Oxford University Press publication by visiting the Oxford University Press website at www.oup.com 


\section{Contents}

Preface vii

Introduction I

I. Global Protection for Inventions 9

I.I The Territorial Limitations of Patent Protection II

I.2 A World Patent is

I.3 Parallel Patents i8

I.3.I Obtaining a Patent Abroad 19

I.3.2 Obtaining Patents in Multiple Countries 25

I.4 Obstacles to Global Protection 35

\section{Enforcing Parallel Patents 39}

2.I Private International Law Solutions to the Problem of Enforcement of Parallel Patents 43

2.I.I The Brussels Regime 44

2.I.2 Mitigating the Problems Created by the Brussels Regime 49

2.I.3 The Hague Convention 58

2.I. 4 The ALI Principles 59

2.I.5 The CLIP Principles 62

2.I.6 Obstacles to Implementation of Private International

Law Solutions 64

2.I.6.I Foreign Patents in U.S. Courts 65

2.I.6.2 Foreign Patents in German Courts 69

2.2 Institutional Solutions to the Problem of Enforcement of Parallel Patents 72

2.3 Obstacles to the Enforcement of Parallel Patents 76 
3. Protecting an Invention outside the Protecting Country $8 \mathrm{I}$

3.I Inventions in the Means of Transportation 84

3.2 Inventions in Transit and Border Measures 88

3.3 Offers to Sell 98

3.4 Inventions Assembled Abroad from Components

from a Protecting Country ios

3.5 Acts Abroad Contributing to Infringements in the Protecting Country IIo

3.6 Acts in Multiple Locations 116

3.7 Limits on the Protection of an Invention outside the Protecting Country I2I

\section{Limits of Protection under the Law of the Protecting Country 127}

4.I Foreign Parties before U.S. Courts-A Quantitative View

of the Enforcement Problem I29

4.I.I Patent Cases Filed in 2004 and 2009133

4.I.2 Cases Involving Foreign Parties 135

4.I.3 Cases Involving at Least One Foreign Defendant and Cases with Only Foreign Defendants 139

4.I.4 Some Observations about the Data on the Involvement of Foreign Defendants in Patent Litigation in 2004 and 2009146

4.2 Injunctions 154

4.2.I Cross-Border Injunctions in U.S. Courts 156

4.2.2 Cross-Border Injunctions in Europe I6I

4.2.3 Challenges to Enforcement of Injunctions Abroad 165

4.2.3.I Enforcement of an Injunction 166

4.2.3.2 Enforcement of a Contempt Order 172

4.3 Monetary Relief 173

4.3.I Punitive Damages 174

4.3.2 Ongoing Royalties 176

4.4 Additional Requirements of Recognition and Enforcement 178

4.5 Obstacles to Enforcement Abroad I8I

CONCLUSIONS I85

BIBLIOGRAPHY 193

TABLE OF CASES 2IS

INDEX 225 


\section{Preface}

AS THE TITLE suggests, this book discusses patents from the global or international perspective. The book is intended primarily for an academic audience; however, it will also be of interest to legal practitioners working in the area of intellectual property law, particularly patents, whether in patent prosecution, patent litigation, patent licensing, or other transactional work involving patents. Inventors, investors, and businesses will find this book useful for learning about the challenges they will face when they encounter patent-related issues that cross national borders. With increasing globalization, such encounters are likely to become more frequent than they have been before, and advance knowledge of the landscape will be essential for operating successfully in a globalized economy.

This book is not the first publication concerning international intellectual property law, or the intersection of intellectual property law and private international law, also referred to as "conflict of laws" in common law countries. Numerous studies exist on the topic of international intellectual property law, the body of law that has developed through international treaties - treaties that specifically address intellectual property issues, and treaties that cover such issues together with other topics, for example, trade-related treaties and agreements.

As compared to the tradition of studies in international intellectual property law, the history of the literature discussing the interplay between intellectual property law and private international law is relatively recent. But in this area several important works have already been written as well, including a major treatise by 
James Fawcett and Paul Torremans, Intellectual Property and Private International Law, originally published by Oxford University Press in 1998, now in its second edition from 201 I.

As opposed to other monographies that analyze issues of private international law and intellectual property law by considering all types of intellectual property, this book focuses solely on patents. This focus might be surprising to readers who are aware of the functioning of national patent systems, which are known for being strictly territorially limited, and affording rights only in the country in which the patent was granted. At first glance it appears that the functioning of patent systems rules out any cross-border problems by definition, but this book points out the wide variety of cross-border issues that are associated with the enforcement of patents.

This book addresses cross-border patent problems in a comprehensive manner; it does this through the view of an inventor or other prospective patent applicant who wishes to protect an invention globally, or at least in as many countries as possible, and who strives to enforce his rights regardless of where acts of infringement occur, or where infringers or their assets happen to be located. The book provides not only new perspectives, such as a comparative analysis of U.S. and German rules on enforcement of national patents beyond national borders, and recent statistical data, such as original statistics on U.S. patent cases, but it also advances topics that have been discussed in other studies, such as the history of patent law internationalization. By covering a large scope of cross-border patent enforcement issues, the book enriches readers' knowledge of the history of patent law internationalization, the development, current state, and possible future trajectory of international patent law, the extraterritoriality of national patent laws, and problems at the intersection of private international law and patent law.

This book is the result of a multiple-year project that could not have been undertaken without the invaluable support of many members of the Stanford Law School community and others who contributed their advice and guidance. My special thanks go to Professor Paul Goldstein; Professor Deborah Hensler, the Associate Dean for Graduate Studies; Professor Amalia Kessler; and Professor Mark Lemley of Stanford Law School. My work benefited greatly from the assistance of the staff of the Robert Crown Law Library at Stanford Law School. Particularly, I would like to express my gratitude to Paul Lomio, the Director of the Library; Sonia Moss; and Sergio Stone. I could not have conducted this research without the Stanford IP Litigation Clearinghouse database, later Lex Machina, Inc.; I would like to thank Professor Mark Lemley and Joshua Walker, the CEO of Lex Machina, Inc., for arranging for me to have early access to the database. 
My research for this book was supported by the Ewing Marion Kauffman Foundation and Stanford Law School. My knowledge of the European legal landscape and particularly German law was greatly enhanced by a research stay at the Max Planck Institute for Intellectual Property and Competition Law, which was made possible by dissertation research funding from Stanford Law School. I am grateful to Professor Paul Goldstein; Professor Joseph Straus, a Director Emeritus of the Institute; Professor Josef Drexl, the current Co-Director of the Institute; and Dr. Peter Weber, the Director of the Institute's Library.

There are a number of other individuals who assisted me with my research for this book; they provided advice, interviews, comments on various drafts, and encouragement. From among the many I would like to mention Professor Barton Beebe, Matthew L. Cutler, Professor Graeme Dinwoodie, Professor Rochelle Dreyfuss, Professor Branislav Hazucha, Blair Jacobs, Philippe de Jong, Judge Thomas Kaess of the München Landgericht, Professor Annette Kur of the Max Planck Institute for Intellectual Property and Competition Law, Michael S. Nadel, WIPO Deputy Director General for Patents James Pooley, and Judge Paul Springer of the Siegen Amtsgericht.

I would like to thank my family for their support, without which my achievements would not be possible. I could not have progressed to this point without the loving support of my husband, Gary A. Trimble. To him I owe many thanks for his patience during countless discussions about my research and for his superb editing advice and many substantive comments.

The text of this book reflects the state of the law as of June I, 20II. 


\section{Protecting an Invention outside the Protecting Country}

THE COSTS OF obtaining patents in multiple countries and the additional costs of any enforcement actions place limits on the number of patents that inventors can secure and the number of countries in which they can enforce their patents. If patent holders face exploitation of their inventions in countries where they hold no patents or where they cannot afford to litigate, they can turn to a protecting country in which they hold patents and attempt to use that country's patent laws to fight the exploitation of their inventions in other countries. Additionally, patent holders may have other reasons why they might attempt to "stretch" the patent law of one protecting country. Relying on the patent law of some particular protecting country will allow a patent holder to place infringement litigation into that country and take advantage of the country's procedural and substantive rules. This chapter analyzes the various doctrines that have been developed and applied to extend national patent protection to the exploitation of inventions beyond the borders of protecting countries.

There is nothing to stop a third party from exploiting an invention outside a protecting country; inventions not protected may be freely utilized, and inventors enjoy no exclusive rights in countries where they have no protection. The only possibility 
inventors have to benefit directly ${ }^{1}$ from the exploitation of their inventions outside protecting countries is to apply quickly for patents in other countries. As long as the term during which international priority is afforded to their applications ${ }^{2}$ has not expired, they may apply for patents in any of the countries in the world that are parties to the Paris Convention. ${ }^{3}$ However, expiration of the international priority period is not the only hurdle to patenting in other countries; high costs and varying standards of patentability are also barriers to applying for and obtaining patents in multiple countries. ${ }^{4}$

For inventors, free exploitation outside the protecting countries is at minimum an economic loss; the disclosure of their inventions is not limited to the protecting countries, but is global, and yet the benefits promised in exchange for the disclosure are limited to the protecting countries. Additionally, it may be impossible to segregate the exploitation of inventions outside the protecting countries from the effects of such exploitation on the markets of the protecting countries; the exploitation can contribute to subsequent acts of infringement inside the protecting countries. For instance, a manufacturer of a patented vehicle air conditioning unit may be acting entirely outside the protecting country but its units may eventually be installed by others in vehicles imported into a protecting country. ${ }^{5}$ Inventors will attempt to mitigate losses they have incurred that were the result of a lack of patent protection in certain countries; for instance, some patentees may introduce upgrades or accessory products that they will patent in those countries to capture some of the income lost because of the lack of patent protection for the original invention. Inventors may also try to rely on protection under other intellectual property doctrines, such as trademark or copyright law, to remedy the losses. However, such mitigating approaches will not fully replace the losses suffered because of the original lack of patent protection.

The use of the patent law of a protecting country to cover acts that occur in a nonprotecting country has long been employed by patentees; observations of the phenomenon were made many decades ago. For instance, in I93I a patent expert

\footnotetext{
${ }^{1}$ There may be indirect benefits to inventors stemming from widespread use of their inventions; for instance, the inventions may become standards in an industry and help the inventors to introduce their related inventions to the markets in countries where they had no protection.

${ }^{2}$ Paris Convention, Chapter I, note 63, Article 4.

${ }^{3}$ There were 173 contracting parties to the Paris Convention as of July 201 I. Information by the WTO, available at http://www.wipo.int/export/sites/www/treaties/en/documents/pdf/paris.pdf and http://www.wipo.int/ treaties/en/statistics/StatsResults.jsp?treaty_id=2\&lang=en (last visited Sept. 2, 201I).

${ }^{4}$ See Chapter I, note 2 and Chapter 2, note 5 and the accompanying text for discussions of the costs of patenting and enforcing patent rights.

${ }^{5}$ See infra note 210.
} 
suggested that this avenue was an understandable and required strategy for small and medium-sized enterprises. The expert, a German patent attorney, pointed out that because such enterprises lacked the resources to patent their inventions outside Germany, they needed to rely on German law to protect them worldwide. ${ }^{6}$

This chapter analyzes the doctrines used to prevent the exploitation of inventions outside protecting countries. Section 3.I covers the first mid-nineteenth-century cases that involved inventions embedded in foreign ships that entered ports of protecting countries. Section 3.2 discusses the cases in which the transit of goods through territories of protecting countries provided an opportunity for inventors to block the utilization of their inventions in other countries; the section also reviews border measures developed to block the importation of infringing products. Sections 3.3 and 3.4 analyze offers to sell and the issue of preventing patent infringements through the supply of components of a patented invention for assembly abroad. Acts of indirect infringement performed abroad may be also infringing, as discussed in Section 3.5. The standard used to localize an infringing act, if defined flexibly enough, may also place an act committed abroad within the scope of the patent law of a protecting country, and such possibilities are discussed in Section 3.6, which also addresses infringements committed on the Internet. Section 3.7 summarizes the various doctrines and explores the limitations of their territorial reach.

The chapter examines the doctrines from a comparative perspective by drawing from legislation and jurisprudence in the United States and Germany. Because any analysis of German law must include the European Union framework applicable in Germany, references are made to European Union law and case law of the Court of Justice of the European Union (CJEU). By reviewing the situation in both the United States and Germany this chapter provides a unique comparative and comprehensive picture of the issues as they arise in both jurisdictions; although various concepts analyzed in this chapter have been discussed in the literature of both countries, ${ }^{7}$ the doctrines and their application in the U.S. and German legal regimes have rarely been compared side by side, ${ }^{8}$ and never in a comprehensive manner. The analysis shows that U.S. law does not exceed the reach of German patent law,

\footnotetext{
${ }^{6}$ Siegfried Meier in i93i Mitteilungen vom Verband deutscher Patentanwälte 95.

${ }^{7}$ In the United States, see, for instance, Dan L. Burk, Patents in Cyberspace: Territoriality and Infringement on Global Computer Networks, 68 Tul. L. Rev. I (1993); Curtis A. Bradley, Territorial Intellectual Property in an Age of Globalism, 37 VA. J. InT'L L. 505 (1997); Chisum, Chapter I, note 173; Holbrook, Territoriality, Chapter I, note 5; Timothy R. Holbrook, Extraterritoriality in U.S. Patent Law, 49 WM. \& MARY L. Rev. 219 (2008). In Germany, see, for instance, Dieter Stauder, Patentverletzung im grenzüberschreitenden Wirtschaftsverkehr (1975); Stauder, Cross-Border, Chapter 2, note 60, 497-504.

${ }^{8}$ Dieter Stauder, Patent Infringement in Export Trade-The Vulnerable Combination Patent, 3 IIC 49I (1972); Jacob A. Schroeder, So Long as You Live Under My Roof, You'll Live By... Whose Rules?: Ending the Extraterritorial
} 
and suggests that the problems of cross-border enforcement, which are further studied in detail in Chapter 4, are not unique to U.S. law, but are problems that are shared by other legal systems as well.

It is important to note that the goal of this chapter is not to address all legal and practical problems associated with the doctrines and their applications, since most of the doctrines deserve their own independent studies. Rather, the goal is to provide an overview of all the various ways in which patent laws of one country have been applied to cover acts committed outside that country and compare the situations in the United States and Germany. The two countries, which are the primary patent litigation jurisdictions in the world, ${ }^{9}$ have a great number of materials for the study of the phenomenon; ${ }^{10}$ they are not the jurisdictions of choice only because they provide advantageous legal mechanisms, but also because they are among the primary countries in the world for the exploitation of inventions.

\subsection{Inventions in the Means of Transportation}

What might be the oldest reported cases that evidence attempts to reach inventions beyond the borders of a protecting country are those involving devices embedded in ships. Ideally, inventors of those devices should have obtained patent protection in the countries where the ships were manufactured or from which they were operated or both; patent protection in those countries would have allowed the inventors to stop the manufacture or operation of the ships. Because they did not secure patents in those countries, the inventors turned to the patent protection that they had in countries to which the ships sailed, and by claiming infringement of their patents in these countries of destination, the inventors at least tried to prevent the temporary presence of the ships in the territory of these protecting countries. The cases brought by patent holders in these instances did not test the territorial boundaries of patent laws; rather, they tested the limits of the temporariness of the allegedly infringing act.

Countries eventually agreed on a unified approach to the problem of inventions embedded in a means of transportation when the 1925 Revision Conference on the

Application of Patent Law, i8 Tex. Intell. Prop. L.J. 55, 77-8I (2009); Lucas S. Osborn, Deconstructing an "Offer to Sell" in the Patent Infringement Context, draft paper, on file with the author.

${ }^{9}$ For statistics on and a discussion of the German patent litigation system, see Mes, Chapter 2, note 177.

${ }^{10}$ In the United States, 2,847 patent cases were filed in federal district courts in 2010. Lex Machina, Chapter 4, note 6, as of June 6, 20II. According to estimates, about I,200 patent cases are filed in Germany every year. Mes, Chapter 2, note 177, 402 . 
Paris Convention added Article ster dealing specifically with the issue of inventions in means of transportation; since that time attacks on such inventions appear only sporadically to test the limits of the provision. The two cases that paved the way to the approach that was adopted in 1925 were an English case from 1851 and a U.S. case from I855; because there is an interesting connection between the cases it is useful to examine both of them.

The issue of a patented device in the construction of a foreign ship was first addressed in an English court in I851. ${ }^{11}$ Vice-Chancellor Turner had a case before him in which the assignees of a patent concerning a propeller ${ }^{12}$ requested an injunction to prevent the defendant's steam vessel from entering English waters, which the vessel regularly did on its route between Amsterdam and London. It was the first and apparently the only instance in which the assignees, who were serial plaintiffs, ${ }^{13}$ targeted these particular foreign defendants. The defendants did not dispute the fact that ships in English waters were subject to English laws; they argued instead that they knew nothing about the plaintiff's English patent and that the plaintiffs held no corresponding patent in Holland where the vessel was built.

Strong policy arguments were made by both sides. The plaintiffs suggested that no exception should be made for foreigners and urged the court to rule against the Dutch defendants because permitting the defendant's behavior would mean that in any similar situation "any foreigner [could] infringe an English patent." ${ }^{14}$ In an affidavit introduced by the defendants, the master of the ship emphasized the importance of steamship transportation at that time and noted that ships using the propeller were the prevailing means of transportation between Holland and England and facilitated trade that "in his judgment and belief, [was] of great advantage to both the said countries." 15

The Vice-Chancellor granted the injunction. He noted that he could not deny an injunction merely because the defendants were foreigners; "foreigners," in his words, "are in all cases subject to the laws of the country in which they may happen to be."16 As for the argument relating to the impediment of trade between the two countries,

\footnotetext{
${ }^{11}$ Caldwell v. Van Vlissengen, I85 I (Eng.), reported by Francis Fisher, Esq., I6 Jurist o.s. iI5 (I853).

${ }^{12}$ The patent at issue was "granted to James Lowe, in the year 1838 , for a mode of propelling vessels by means of one or more curved blades set or affixed on a revolving shaft below the water line of the vessel, and running from stem to stern of the vessel." Caldwell, supra note in, in6.

${ }^{13}$ It is notable that the plaintiffs litigated several cases in which they successfully withstood attacks on the validity of the patent by reaching settlement with defendants before the issue of validity was decided.

${ }^{14}$ Caldwell, supra note iI, i17.

${ }^{15}$ The affidavit by Tzebbe Swart, quoted in Caldwell, supra note II, II7.

${ }^{16}$ Caldwell, supra note II, in 8. In support of his conclusion he quoted several authorities, including Justice Story and Ulrich Huber, cited the applicable English statute, and also referred to natural justice. Id., II9.
} 
he reasoned that an equal treatment of English and Dutch ships would actually level the playing field, as all ships would be required to obtain licenses to use the invention patented in England if they wanted to service English waters.

At the conclusion of his decision, Vice-Chancellor Turner suggested that it was upon the legislature to change the law if policy considerations dictated a different result. ${ }^{17}$ Thereafter, his words were rapidly translated into action by Parliament and also confirmed by later developments in the United States. As Turner envisioned, his decision was legislatively overruled; the Solicitor General, who was personally involved in the case, authored the relevant amendment to the Patent Act that inserted a provision protecting foreign vessels against the claims of holders of English patents. ${ }^{18}$ When the similar case of John Brown v. Duchesne ${ }^{19}$ was brought later before the Circuit Court of the United States, Massachusetts District, and ultimately before the U.S. Supreme Court, American justices inquired about the outcome of the English case, and their decisions were influenced by the developments in England.

Although the facts and governing law in Duchesne were similar to those faced by Vice-Chancellor Turner, the outcome in Duchesne was completely different from the one in the English case because the U.S. decisions followed the legislative overruling of the English case in the English Patent Act. The patent involved in Duchesne covered a device used in a French vessel that was alleged to have infringed a U.S. patent when the vessel entered the port of Boston. Judge Curtis of the Massachusetts District, having recognized the prescriptive and adjudicatory power of countries to regulate ships that enter their ports, ${ }^{20}$ interpreted the U.S. patent statute as not "designed to touch the subject of the structure or equipment of foreign vessels." $\mathrm{He}$ also suggested that at minimum it was "extremely questionable" whether patentees should be able to obtain damages or compensation in situations similar to the one presented in Duchesne; in his opinion the use of an invention covered by a U.S. patent in U.S. waters by a foreign ship would be "almost an unappreciable part of the use of a thing patented."21

The U.S. Supreme Court agreed with Judge Curtis; ${ }^{22}$ having emphasized the territorial scope of patent laws, the Court noted that " $[\mathrm{t}]$ he chief and almost only advantage which the defendant derived from the use of the [invention] was on the

\footnotetext{
${ }^{17}$ Caldwell, supra note II, I2O.

${ }^{18}$ H. Geoffrey Lynfield, Patent Infringement on British and American Ships, 37 J. PAт. Off. Soc'y 389, 390 (1955).

${ }^{19}$ John Brown v. Duchesne, 4 Am. L. Reg. I52 (C.C. Mass. 1855); Brown v. Duchesne, 60 U.S. 183 (1856).

${ }^{20}$ John Brown v. Duchesne, 4 Am. L. Reg. 152, I55 (C.C. Mass. 1855).

${ }^{21} I d$., 157 .

${ }^{22}$ Brown v. Duchesne, 60 U.S. 183 (1856).
} 
high seas and in other places out of the jurisdiction of the United States." ${ }^{23}$ The Court saw no damage to the plaintiff and no advantage to the defendant stemming from the use of the invention in this case; even if there was some damage or advantage, the Court deemed it to be "so minute that it [was] incapable of any appreciable value." 24 The Court held that "the rights of property and exclusive use granted to a patentee [did] not extend to a foreign vessel lawfully entering one of [the U.S.] ports." 25

Following the decisions in Caldwell and Duchesne on the issue of inventions of components used in the building of ships, countries began to protect ships temporarily entering their ports from patent infringement claims. In the United States the problem was solved by the statutory interpretation in Duchesne; a specific statutory provision on the issue was adopted only much later in $1952 .{ }^{26}$ Other countries, including Germany, followed the lead of Great Britain and adopted statutory provisions protecting foreign ships in their waters even earlier than the United States. ${ }^{27}$

At the international level the exception was embraced in 1925 through the insertion of Article ster to the Paris Convention $;{ }^{28}$ this article provides protection to those who use inventions on board the vessels of countries of the Paris Union as long as the vessels "enter the waters of the country" only "temporarily or accidentally" and the invention is "used there exclusively for the needs of the vessel." ${ }^{29}$ Article ster also resolved the question of whether the same exception should apply for means of transportation that use air or ground instead of water; the 1925 Revision Conference included both air and ground transportation..$^{30}$ Article ster paragraph 2 states that inventions may be used in countries of the Union if they are used "in the construction or operation of aircraft or land vehicles" and also under the condition that they enter only "temporarily or accidently."

\footnotetext{
${ }^{23} I d ., 196$.

${ }^{24} I d ., 196$.

${ }^{25} I d ., 198$.

${ }^{26} 35$ U.S.C. $\$ 272$.

${ }^{27}$ Lynfield reported that by 1907 six other countries had adopted such a provision, including the AustroHungarian Empire and Germany. Lynfield, supra note 18, 394. See \$5 of the German Patent Act of Apr. 7, I891; reprinted in Julius Küster, Patent-, Muster- und Marken-Schutz in der Motoren- Und FAHRZEUG-INDUSTRIE 5 I (1908).

${ }^{28}$ Bodenhausen, Chapter I, note 68, 82 .

${ }^{29}$ Paris Convention, Chapter I, note 63, Article ster(I).

${ }^{30}$ By this time, in fact, the 1919 Convention Relating to the Regulation of Aerial Navigation already protected foreign aircraft from seizures in protecting countries. Cf. Joseph H. Beale, who in 1923 remarked that it was "perhaps too soon to assert dogmatically" whether air transportation was to be viewed analogously. Joseph $\mathrm{H}$. Beale, The Jurisdiction of a Sovereign State, 36 HARv. L. REV. 241, 262 (1922-1923).

${ }^{31}$ Paris Convention, Chapter I, note 63, Article ster(2). On details of the negotiations of Article ster, see Lynfield, supra note 18, 397-98. See also Convention on International Civil Aviation, Dec. 7, 1944 (Chicago Convention), Article 27; the United States adhered to the Convention in 1946, and Germany in 1956. As of September 2011,
} 
Since the 1925 Revision of the Paris Convention, cases have been brought that have further refined the notion of "temporariness" used in Article ster. For instance, in 1974 the U.S. District Court for the Eastern District of New York interpreted the term in Cali v. Japan Air Lines, ${ }^{32}$ in which the defendants, who were various international air carriers, were accused of infringing a U.S. patent concerning JT-4 jet engines. The plaintiff argued that there was nothing "temporary or accidental" in "the maintenance of a regular and systematic international aircraft service to the U.S." ${ }^{33}$ The court noted that the exception provided by Article ster of the Paris Convention and the corresponding provision of Section 272 of the U.S. Patent Act was a substantial "subtraction from the grant" to the patent holder in Cali, and although it found that the magnitude of operations of the foreign carriers was comparable to those of U.S. carriers, the court adopted a broad interpretation of the term "temporarily" and found no infringement of the patent. ${ }^{34}$ Recently, the U.S. Court of Appeals for the Federal Circuit formulated its own definition of the term as used in Section 272; in National Steel Car, Ltd. v. Canadian Pacific Ry., Ltd. it stated that "temporarily' [...] is entering for a period of time of finite duration with the sole purpose of engaging in international commerce."35

\subsection{Inventions in Transit and Border Measures}

Even after inventions in the means of transportation that only temporarily entered protecting countries became protected from attacks by patent holders, the activities of transportation or transit of goods through protecting countries continued to offer opportunities for inventors to block transportation channels and fully or partially

there were 190 contracting parties to the Convention. See http://www.icao.int/icao/en/leb/chicago.pdf (last visited Sept. 2, 2011). For issues of patent protection in outer space and other "extraterritorial areas," see, e.g., Dieter Stauder, Patent Protection in Extraterritorial Areas (Continental Shelf, High Seas, Air Space, and Outer Space), 7 IIC 470 (1976); Friedrich-Karl Beier \& Dieter Stauder, Weltraumstationen und das Recht des geistigen Eigentums, 1985 GRUR InT. 6; Karl-Heinz Böckstiegel, Paul Michael Krämer, \& Isabel Polley, Kann der Betrieb von Satelliten im Weltraum patentrechtlich geschützt werden?, I999 GRUR I.

${ }^{32}$ Cali v. Japan Air Lines, 380 F. Supp. 1120 (E.D.N.Y. 1974).

${ }^{33} I d$., $\mathrm{I} 124$.

${ }^{34}$ A similar refinement of "temporariness" was provided in the United Kingdom in Stena Rederi AB and Stena Line AB v. Irish Ferries Ltd., [2003] EWCA Civ 66; [2003] R.P.C. 36 (Eng.). Although the vessel at issue, a catamaran, which included in its construction an invention patented in the United Kingdom, sailed between Ireland and the United Kingdom three or four times a day, the court held that unless the vessel's presence in U.K. waters was permanent, no injunctive relief could be granted.

${ }^{35}$ National Steel Car, Ltd. v. Canadian Pacific Ry., Ltd., 357 F.3d I319, 133I (Fed. Cir. 2004). On the opportunity to take advantage of the exception, see J. Jonas Anderson, Hiding Behind Nationality: The Temporary Presence Exception and Patent Infringement Avoidance, is Mich. Telecomm. \& TeCH. L. Rev. I, 40-44 (2008). 
prevent utilization of their inventions abroad. Countries have hesitated to permit such actions targeting goods in transit-there are important reasons to ensure that goods be allowed to be transported safely through the territory of a protecting country on their way from one country to another.

An inventor who holds a patent in a country through which the goods are transported must find a "hook" - a reason for the country to be willing to entertain an action targeting the goods. A danger that the goods might "leak" from transit into the market of the protecting country is such a reason. Countries have distinguished between pure transit, where the goods should be protected from such attacks, and other activities that go beyond pure transit, may result in "leakage," and should be subject to attacks; as two German commentators explained, the difference is between pure transit that is "the simple uninterrupted transport through or over the territory" ${ }^{36}$ and "other forms of transit [that] may include activities such as storage in a customs free zone, repackaging, etc." ${ }^{37}$

Given the different geographical locations of the United States and Germany, it is not surprising that the issue of transit has been discussed frequently in Germany but has not been developed in U.S. case law. German jurisprudence provides numerous cases on patent infringing goods in transit, and recent German cases reflect developments in the European Union that may have far-reaching consequences for those who transport goods patented in member states of the European Union through the territories of those member states.

The issue of transit was a subject of discussion in Germany from the time of the enactment of the first Patent Act of the German Empire in $1877,{ }^{38}$ as recalled by the Reichsgericht in an 1899 decision. ${ }^{39}$ The 1877 and 1891 Patent Acts granted exclusive rights to manufacture, sell, offer to sell, and use the patented invention, ${ }^{40}$ and the question from early on was one of demarcation between pure transit and an activity that was more accurately labeled a sale or offer to sell. The oldest transit cases

\footnotetext{
${ }^{36}$ Alexander von Mühlendahl \& Dieter Stauder, Territorial Intellectual Property Rights in a Global EconomyTransit and Other "Free Zones," in Patents and Technological Progess in a Globalized WorldLiber Amicorum Joseph Straus 653, 659 (Wolrad Prinz zu Waldeck und Pyrmont, Martin J. Adelman, Robert Brauneis, Josef Drexl, \& Ralph Nack eds., 2009).

${ }^{37}$ Mühlendahl, Stauder, supra note 36, 659.

${ }^{38}$ For the pre-1877 history of patent law in the German territory, see, e.g., KLOSTERMANn, Chapter 1, note 60, 103 ff.; Margrit Seckelman, Industrial Engineering and the Struggle for the Protection of Patents in Germany, 1856-1877, 5 QUaderns D'Història De L'Enginyeria 234 (2002-2003); Krasser, Chapter I, note is, 58-64. For an overview of German patent law since 1877 , see $i d ., 64-69$.

${ }^{39}$ Reichsgericht, I 324/99, Dec. 2, I899, RGZ 45, I47. The court noted that the decision in that particular case did not require it to take a position on the controversy surrounding the issue of transit. $I d$., I 48 .

${ }^{40} \$_{4}$ of the Patent Act of 1877 ; $\$ 4$ of the Patent Act of 189 I. The terms used being "herstellen, in Verkehr bringen, feilhalten, gebrauchen."
} 
before the German Supreme Court—at that time called the Reichsgericht-bore two characteristic features: first, they were criminal cases, since criminal prosecution for patent infringement was possible under the Patent Act, and if one knowingly infringed patent rights, he could be criminally prosecuted; ${ }^{41}$ and second, they involved transit through the port of Hamburg, which was not only an extremely important transportation hub but also a customs-free zone.

In the early cases defendants relied on the status of the customs-free zone to provide protection for their dealings with products that included patented inventions. For instance, in 1884 the Reichsgericht considered a case in which goods were shipped from a manufacturer in Holland to the defendants' storage in the port of Hamburg, where the defendants repackaged the goods and offered them for sale to their customers abroad. ${ }^{42}$ Both the Hamburg Landgericht and the Reichsgericht interpreted the conduct as acts of infringement (sale, offer to sell) committed by the defendants in Germany. The Reichsgericht reached the same result in a similar criminal case in 1890 ; in that decision the court emphasized that although the goods at issue were not subject to German customs because of the customs-free zone in the port of Hamburg, the presence in the zone did not exclude the goods from application of German laws, including the Patent Act. ${ }^{43}$

A case that seemed more difficult was decided by the Reichsgericht in $1899 ;{ }^{44}$ the defendants arranged for goods to be sent from Milan to their corporate headquarters in Hamburg from which they shipped the goods to customers in Sydney. The goods remained in the customs-free zone in Hamburg and were not removed from their original packaging. Although the lower court classified the activity as transit and found no infringement, the Reichsgericht disagreed and held that the defendants acted not as carriers but as buyers and sellers of the infringing product, and that therefore their acts were not acts of transit but of import and export involving the sale of goods.

In later cases German courts continued to distinguish between "transit in a strict sense" and "transit in a broader sense," holding that only the former is a noninfringing activity. ${ }^{45}$ For instance, in $198 \mathrm{I}$ in Rollwagen ${ }^{46}$ the Karlsruhe Oberlandesgericht

\footnotetext{
${ }^{41} \$ 34$ of the Patent Act of $1877 ; \$ 36$ of the Patent Act of 1891 .

${ }^{42}$ Schmierbüchsen, Reichsgericht, 626/84, Apr. 3, 1884, RGZ 104, 349.

${ }^{43}$ Antipyrin, Reichsgericht, $1865 / 90$, Oct. 25, 1890, RGZ 76, 205. In this case the defendant bought the patented product in Basel and had it shipped to the Hamburg customs-free zone, where he stored it and only from there sold it to clients abroad.

${ }^{44}$ Reichsgericht, I 324/99, Dec. 2, 1899, RGZ 45, 447.

${ }^{45}$ Taeschner-Pertusin, Bundesgerichtshof, Jan. 15, 1957, 1957 GRUR 195 (a trademark case). The Bundesgerichtshof speaks in the case about a "Durchfuhr im engeren Sinne" and a "Durchfuhr im weiteren Sinne." Id.

${ }^{46}$ Rollwagen, Oberlandesgericht Karlsruhe, 6 U 173/80, Dec. 23, 1981, 1982 GRUR INT. 752, 1982 GRUR 295.
} 
refused to hold that the defendant's shipment of goods to Kuwait constituted a transit, even when the shipment was made from Switzerland free on board ${ }^{47}$ to the German port of Bremerhaven and from Bremerhaven to Kuwait on board a ship under the Dutch flag. The court noted that the product was in fact offered for sale and sold in Germany and that the defendant personally attached its own label to the product when it was loaded on the ship in the customs-free zone of the port of Bremerhaven. The court restated the rule that although customs-free zones are excluded from certain customs regulations, they fall within the territorial scope of German patent law; ${ }^{48}$ the court then reiterated the position of the Bundesgerichtshof that " $[t]$ he criterion that distinguishes a mere transit permitted by patent laws and importation for the purposes of export that infringes a patent is whether the product that falls within the scope of a German patent is an item of sales business that exhibits sufficient connection with [Germany]."49

The rule, then, is that shipment free on board does not protect an infringer if the infringer in fact takes control over the goods in Germany..$^{50}$ In Rollwagen the Karlsruhe Oberlandesgericht attached significance to the fact that although the goods were shipped free on board, they were in defendant's control in the German port when the defendant personally attached his own label to the goods. Similarly, in Trimethoprim ${ }^{51}$ the Hamburg Hanseatisches Oberlandesgericht ruled that if goods are shipped from abroad and while in Germany they become available to the defendant, the situation does not qualify as pure transit; there is infringement, and it does not make a difference "whether the goods are supposed to remain in [Germany] or be exported abroad." 52

As the cases above illustrate, German jurisprudence on the issue of transit is consistent; however, there was a brief period of uncertainty in 2004-2007 caused by the CJEU's interpretation in two trademark cases of the notion of transit under European Union law, ${ }^{53}$ specifically, the European Union Customs Regulation. ${ }^{54}$ Although the TRIPs Agreement does not require countries to adopt customs

\footnotetext{
${ }^{47}$ See infra note 231 and the accompanying text on the term "free on board."

${ }^{48}$ Rollwagen, supra note 46.

${ }^{49} I d ., 299-300$.

${ }^{50}$ See also infra Section 3.6 for a discussion of the effects of a free on board shipment.

${ }^{51}$ Trimethoprim, Hanseatisches Oberlandesgericht Hamburg, 3 U I/90, Oct. 25, 1990, 1990 GRUR INT. 30 I.

${ }^{52}$ Id., 301 and 302. See also Imidazol, Oberlandesgericht Hamburg, 3 U I2/85, Apr. 25, 1985 , 1985 GRUR 923.

${ }^{53}$ Case C-383/98, Polo/Lauren v. Dwidua, 2000; Case C-60/02, Re Montres Rolex SA, 2004.

${ }^{54}$ Council Regulation (EC) No $1383 / 2003$ of 22 July 2003 concerning customs actions against goods suspected of infringing certain intellectual property rights and the measures to be taken against goods found to have infringed such rights, 2003 O.J. (L I96) 7 (“2003 Customs Regulation”); Council Regulation (EC) No $3295 / 94$ of 22 December 1994 laying down measures to prohibit the release for free circulation, export, re-export,
} 
measures to target patent infringing goods in transit, ${ }^{55}$ the Regulation does; its original 1994 version did not cover patents, but the amended 2003 version does cover patents. ${ }^{56}$ Inclusion of patents in the regulation was not without controversy; for example, during the legislative process Spain warned that extending the scope of the regulation to cover process patents would create difficulties in practice. ${ }^{57}$

The two trademark decisions by the $\mathrm{CJEU}^{58}$ seemed to suggest that the Regulation would require that many transit situations be classified as importations, ${ }^{59}$ and the Hamburg Landgericht adopted the reasoning of these CJEU trademark cases in a 2004 patent case. ${ }^{60}$ The Landgericht explained that the CJEU case law in the trademark area required the court to interpret the concept of importation in line with the Customs Regulation, which enables customs officials to seize goods that infringe a patent of a member state ${ }^{61}$ when they are transported from a third country to another third country. ${ }^{62}$ This 2004 decision by the Hamburg Landgericht contradicted

or entry for a suspensive procedure of counterfeit and pirated goods, 1994 O.J. (L 34I) 8 ("1994 Customs Regulation”).

55 “[T] here shall be no obligation to apply [customs procedures] to [. . .] goods in transit." Article 5I, fn. I3, TRIPs. "Members may enable such an application [for the suspension by the customs authorities] to be made in respect of goods which involve other infringements of intellectual property rights." (Meaning other than trademarks and copyright.) Article 5I, TRIPs. The Paris Convention includes provisions on seizure of goods upon importation but they concern only marks and trade names. Paris Convention, Chapter I, note 63, Article 9.

${ }^{56}{ }_{2003}$ Customs Regulation, supra note 54, Article 2(I)(c)(i).

${ }^{57}$ General Affairs Council Meeting, 5455/99 (Jan. 25, 1999), XI.

${ }^{58}$ See supra note 53.

${ }^{59}$ In Polo/Lauren T-shirts were in transit from Indonesia to Poland when they were temporarily detained by Austrian customs pursuant to a request by the trademark holder. Polo/Lauren, supra note 53, paras. 16 and 17. Responding to the observation submitted by the government of Germany, the CJEU rejected the interpretation that the 1994 Customs Regulation did not apply to goods that were merely in transit from one nonmember country to another. $I d$., paras. 24 and 25. In Rolex watches were transported from Italy to Poland, meaning, at that time, from a member state to a nonmember country. The CJEU confirmed that the 1994 Customs Regulation applied "to situations in which goods in transit between two countries not belonging to the European Community are temporarily detained in a Member State by the customs authorities of that State." Rolex, supra note 53, para. 64.

${ }^{60}$ Landgericht Hamburg, $315 \mathrm{O} 305 / 04$, Apr. 2, 2004.

${ }^{61}{ }_{2003}$ Customs Regulation, supra note 54, Article 2(I)(c).

${ }^{62} I d$., Article I. It is worth noting that under the particular facts of the case the Hamburg Landgericht might have found infringement through importation even without making any changes to the interpretation of the term "transit." The products were transported through Germany on their way from a Chinese manufacturer to Russian customers. In addition to a somewhat suspicious routing, there was some evidence that at least some of the infringing products were intended for the German market; the court did not believe that German labels on the products that included information likely to be understandable only to a German customer ("TüV," "GS," and "Grüne Punkt") were intended solely to provide the products a "western touch," highly desirable on the Russian market. 
previous German court decisions on the issue of transit, and joined the CJEU trademark decisions as a target of criticism by various commentators. ${ }^{63}$

The CJEU further clarified its position concerning goods in transit in a 2006 trademark case, Montex Holdings Ltd. v. Diesel SpA, ${ }^{64}$ which concerned the transit of jeans through Germany en route from Poland to Ireland. The court described the transit as an "uninterrupted transit from the Polish customs office to the customs office in Dublin" with goods "protected against any removal in the course of transit by a customs seal affixed on the means of transport by the Polish authorities." ${ }^{\text {" The }}$ transit was thus from a then-non-member country to a member state, and although the trademark at issue was protected in Germany where the jeans were detained, the trademark was not protected in Ireland-the destination member state of the goods. The CJEU confirmed that pure transit does not infringe trademarks; ${ }^{66}$ however, it added that pure transit must not involve offers for sale or a sale "effected while the goods are placed under the external transit procedure or the customs warehousing procedure and [the placement] necessarily entails their being put on the market" ${ }^{167}$ in the European Union, or "goods [being] subject to the act of a third party while they are placed under the external transit procedure which necessarily entails their being put on the market in the Member State of transit." ${ }^{\prime 68}$

Since Diesel, the Bundesgerichtshof reconfirmed its approach to transit in the trademark case Durchfuhr von Originalware, ${ }^{69}$ which concerned a U.S. defendant

\footnotetext{
${ }^{63}$ Iouri Kobiako, Durchfuhr als Patentverletzungshandlung?-Zugleich Anmerkung zum Urteil des LG Hamburg vom 2. Apr. 2004, 2004 GRUR INT. 832, 834, 836, and fn. 29. Commentators rejected the proposition that a particular solution for a procedural issue pursued in the Customs Regulation should justify a new interpretation of a substantive right. Kobiako also suggested that the CJEU jurisprudence concerning trademarks might not be relevant in cases involving patents; while in cases involving trademarks the Regulation concerns goods bearing without authorization a registered trademark, in cases involving patents the Regulation speaks of goods that infringe a national patent. Kobiako concludes that a finding of patent infringement must first be made by a court before the Regulation may apply.

${ }^{64}$ Case C-28I/o5, Montex Holdings Ltd. v. Diesel SpA, 2006.

${ }^{65} I d$., para. II.

${ }^{66} I d$., para. 2I. "In the field of trade marks, placing non-Community goods bearing a mark under a suspensive customs procedure such as that of external transit is not, per se, interference with the right of the proprietor of the mark to control the initial marketing in the Community [...]." Id.

${ }^{67} I d$., para. 22. "The external Community transit $\left(\mathrm{T}_{\mathrm{I}}\right)$ procedure, applies mainly to the movement of nonCommunity goods." Transit Manual, TAXUD/A3/0007/2010, July I, 2010, available at http://ec.europa.eu/ taxation_customs/resources/documents/customs/procedural_aspects/transit/common_community/transit_ manual_consolidation_en.pdf (last visited Sept. 2, 2011), 37-38.

${ }^{68} I d$., para. 23. The CJEU added that "[i] $\mathrm{t}$ is [. . ] irrelevant whether goods whose destination is a Member State come from an associated State or a third country, or whether those goods have been manufactured in the country of origin lawfully or in infringement of the existing trade mark rights of the proprietor in that country." Id., the ruling, para. 2.

${ }^{69}$ Durchfuhr von Originalware, Bundesgerichtshof, I ZR 66/04, Mar. 21, 2007, 2007 GRUR 875.
} 
that bought plaintiffs' products in Russia. The plaintiffs intended for the products to be sold in Russia, but the defendant wanted to import them into the United States. The defendant transited the products through Europe; they were flown from Russia, unloaded in Germany at the Frankfurt-Hahn airport, and from there they were supposed to be transported by ground to the port of Bremen and shipped to Miami. German Customs seized the products at the Frankfurt-Hahn airport under suspicion of trademark infringement. In holding that there was no infringement, the court pointed out that trademark laws, legislative history, and the jurisprudence of the CJEU all require that something in addition to pure transit must exist in order to warrant a finding of infringement. ${ }^{70}$ In this case there was no indication that the defendant intended to sell any of the products in Germany; a possibility that the products could end up on the German market was insufficient.

Regardless of the CJEU's decision in Diesel and the position of German courts on the issue of transit, courts of other European Union member states are split in their interpretations of the Customs Regulation and the impact of the Regulation on substantive patent laws; the matter is thus subject to a significant and continuing debate $^{71}$ that has extended beyond European Union borders. Following a seizure by Dutch customs officials of 500 kilograms of generic medicines traveling through the Netherlands in a shipment from India to Brazil, Brazil filed an intervention with the World Trade Organization (WTO) General Council in March 2009. ${ }^{72}$ In the intervention Brazil claims that the action by Dutch customs was a breach of Article V of the General Agreement on Tariffs and Trade (GATT), which codifies the principle

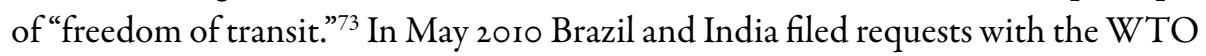
to institute official consultations with the European Union and the Netherlands to resolve the problem of seizures of goods in transit. ${ }^{74}$ For now, the consultations have

\footnotetext{
${ }^{70} I d ., 875$.

${ }^{71}$ Frederick M. Abbott, Seizure of Generic Pharmaceuticals in Transit Based on Allegations of Patent Infringement: A Threat to International Trade, Development and Public Welfare, i World InTEll. Prop. Org. J. 43, 43 (2009). Frederick M. Abbott explains that although customs authorities in other member states have also seized goods that allegedly infringed patents, " $[t]$ he customs authorities of the Netherlands have been the most aggressive." Id., 47 .

${ }^{72}$ Intervention by Brazil, available at http://www.keionline.org/blogs/2009/02/03/intervention-by-brazil-atwto-general-council-on-seizure-of-50o-kilos-of-generic-medicines-by-dutch-customs-aut (last visited Sept. 2, 20II).

${ }^{73}$ Article V, General Agreement on Tariffs and Trade, Oct. 30, 1947, available at http://www.wto.org/english/ docs_e/legal_e/gatt47_or_e.htm (last visited Sept. 2, 20II).

${ }^{74}$ Information by the WTO concerning the request by Brazil, available at http://www.wto.org/english/tratop_e/ dispu_e/cases_e/ds409_e.htm (last visited Sept. 2, 2011), and Information by the WTO concerning the request by India, available at http://www.wto.org/english/tratop_e/dispu_e/cases_e/ds4o8_e.htm (last visited Sept. 2, 20II).
} 
been halted in anticipation of a CJEU decision that should clarify the contentious provisions of the Customs Regulation; the CJEU should issue the decision in response to a request for a preliminary ruling that was submitted by the English Court of Appeal in Koninklijke Philips Electronics NV v. Lucheng Meijing Industrial Co. $L t d .^{75}$

Although German customs do not prevent the mere transit of goods that embed an invention protected in Germany, they continue to employ measures to prevent the importation of goods; both the 2003 European Union Customs Regulation and German patent law provide for seizures of patent-infringing goods by customs. In Germany, goods are seized based on a request filed by a patent holder. Under the German Patent Act, the alleged infringer has two weeks to object to the seizure. ${ }^{76}$ Once the patent holder is notified of the objection, the holder must produce a court order that mandates an impounding or defines the limitations of disposition rights. ${ }^{77}$ Under the 2003 Customs Regulation, the patent holder has ten working days from receipt of notification of suspension of release or of detention of goods to initiate proceedings concerning infringement of goods, which in Germany will be held before a court. ${ }^{78}$

According to statistics by the European Commission, out of over II 8 million articles seized at European Union borders in 2009 because of alleged intellectual property rights infringements, 4.99 percent were targeted because the articles were claimed to infringe a patent. ${ }^{79}$ According to German customs statistics, of all goods subject to actions by German customs in 2009 because of intellectual property rights violations 8.93 percent (measured by value of goods) concerned products claimed to infringe patents; that percentage represented a value of $€ 32.5$ million. ${ }^{80}$

\footnotetext{
${ }^{75}$ See the Request for Preliminary Ruling in Nokia Corp. v. HM Commissioners of Revenue \& Customs, Nov. 9, 2009, available at http://www.eplawpatentblog.com/2010/January/Court\%200f\%20Appeal\%20Order\%20N okia.pdf (last visited Sept. 2, 2011), and the Opinion of Advocate General Cruz Villalón in Koninklijke Philips Electronics NVv. Lucheng Meijing Industrial Co. Ltd., CJEU, C-446/o9.

${ }^{76}$ Patentgesetz, \$1 $42 \mathrm{a}(3)$.

${ }_{77}$ Patentgesetz, \$1 $42 \mathrm{a}(4)$.

${ }^{78} 2003$ Customs Regulation, supra note 54, Articles 9-13. The period may be extended by ten working days, and the period is only three working days for perishable goods. Id., Article I3. See id., Article II, for the possibility of a simplified procedure.

${ }^{79}$ Report on EU Customs Enforcement of Intellectual Property Rights-Results at the EU Border-2009, 2 and I7, available at http://ec.europa.eu/taxation_customs/resources/documents/customs/customs_controls/ counterfeit_piracy/statistics/statistics_2009.pdf(last visited Sept. 2, 2011).

${ }^{80}$ Gewerblicher Rechtsschutz, Statistik für das Jahr 2009, 9 and II, available at http://www.zoll.de/DE/ Fachthemen/Verbote-Beschraenkungen/Gewerblicher-Rechtsschutz/Marken-und-Produktpiraterie/ Statistik/statistik_node.html (last visited Sept. 2, 20II). Most of the actions concerned products claimed to infringe trademarks ( 76.3 percent of value of goods). Id., II. The total value of all goods subjected to actions by German customs in 2009 because of alleged intellectual property rights violations was $€_{3} 63.7$ million, or about
} 
The United States has powerful customs proceedings to fight the importation of goods that infringe intellectual property rights, including patents. Section 337 investigations before the International Trade Commission (ITC) enable holders of U.S. patents to obtain exclusion orders to prevent importation of infringing goods. ${ }^{81}$ Each year two to three dozen cases are brought before the ITC; $; 2$ as of April 20II, of the total of eighty-one outstanding Section 337 exclusion orders, forty-three concerned patents. ${ }^{83}$ The effect of the exclusion orders is strictly limited to U.S. territory, as they "exclude from entry for consumption into the United States, entry for consumption from a foreign trade zone, or withdrawal from a warehouse for consumption, for the remaining term of the patent, except under license of the patent owner." 84

Orders are issued either as "limited exclusion orders" or "general exclusion orders." "General exclusion orders" concern a particular product and any downstream product, wherever the product may originate. "Limited exclusion orders" cover only a particular product by parties specified in the order. Until the 2008 decision by the U.S. Court of Appeals for the Federal Circuit in Kyocera Wireless Corp. v. ITC, ${ }^{85}$ "limited orders" were used to cover not only the infringing products per se, but also downstream products by entities not named as respondents in the particular ITC investigation; however, since Kyocera the ITC may no longer issue limited orders covering downstream products. ${ }^{86}$

ITC proceedings provide a number of advantages when compared to infringement proceedings before a court. Among the advantages that have been appreciated by patentees are the speed of the proceedings, which tends to be faster than proceedings

$\$ 525$ million. Id., 9. The value of goods targeted by U.S. customs for such violations in fiscal year 2008 was \$188.I million, or about $€_{130.3}$ million. Intellectual Property Rights-Fiscal Year 2010 Seizure Statistics, 2, available at http://www.ice.gov/doclib/news/releases/2011/r10316washington.pdf (last visited Sept. 2, 201I).

${ }^{81}$ 19 U.S.C. \$1337. On Section 337 investigations, see, e.g., Colleen Chien, Patently Protectionist? An Empirical Analysis of Patent Cases at the International Trade Commission, 50 WM. \& MARY L. Rev. 63 (2008). On the issue of standing and the "domestic industry" requirement see the ITC decision in Certain Multimedia Display and Navigation Devices and System Components Thereof and Products Containing Same, Inv. No. 337-TA-694, July 22, 201 I.

${ }^{82}$ In 2010 there were fifty-six cases instituted, in 2009 there were thirty-one. See ITC statistics available at http:// www.usitc.gov/intellectual_property/documents/cy_337_institutions.pdf(last visited Sept. 2, 2011).

${ }^{83}$ See list of outstanding Section 337 exclusion orders available at http://www.usitc.gov/intellectual_property/ (last visited Sept. 2, 201I). The number includes orders concerning design patents.

${ }^{84}$ E.g., limited exclusion order in the matter of Certain Coupler Devices for Power Supply Facilities, Components Thereof, and Products Containing the Same, 337-TA-590, Dec. 20, 2007, 2-3; general exclusion order in the matter of Certain Plastic Food Containers, 337-TA-514, May 23, $2005,2$.

${ }^{85}$ Kyocera Wireless Corp. v. ITC, 543 F.3 1340 (Fed. Cir. 2008).

${ }^{86}$ For the impact of Kyocera on ITC proceedings, see Bas de Blank \& Bing Cheng, Where Is the ITC Going After Kyocera?, 25 Santa Clara Computer \& High Tech. L.J. 7 OI (2009). 
before a district court ${ }^{87}$ availability of the "general exclusion orders" that may cover downstream products, ${ }^{88}$ jurisdictional rules that can extend further than the rules applicable to civil litigation in district courts, ${ }^{89}$ the fewer defenses that ITC proceedings allow, as compared to district court proceedings, ${ }^{90}$ and the absence of a fourpart equity test for obtaining an exclusion order. ${ }^{91}$ ITC proceedings are often sought by patentees as a complement to the filing of a suit in a U.S. district court; ${ }^{92}$ the patentees seek rapid relief, and although no damages can be awarded in ITC proceedings, exclusion orders may be valuable both as a prospective remedy and a powerful negotiating tool.

The advantages of ITC proceedings are why they have recently become popular for fighting infringements by domestic infringers, although Section 337 investigations were designed to fight infringing importations by foreign competitors. As Colleen Chien noted in her study on ITC investigations, the "venue [...] has outgrown its original purpose: the ITC is no longer reserved for the specific threat of foreign piracy." ${ }^{13}$ Her survey of recent cases shows that only I 4 percent of investigations were initiated solely against foreign respondents; $;{ }^{94}$ in 72 percent of cases, investigations concerned both foreign and domestic respondents. ${ }^{95}$ The remaining investigations targeted only domestic respondents. ${ }^{96}$

Although border measures are by definition directed against infringements that emanate from outside the protecting country, they do not generally create crossborder enforcement difficulties; the measures, like the ones in Germany and the United States, rely on domestic enforcement-enforcement by the countries' respective national customs authorities - and no need for cross-border enforcement arises.

\footnotetext{
${ }^{87}$ De Blank \& Cheng, supra note 86, 704.

${ }^{88} I d ., 705$.

${ }^{89} \mathrm{Id} ., 707$.

${ }^{90}$ Chien, supra note 81, 79; de Blank \& Cheng, supra note 86, 707-08.

${ }^{91}$ Chien, supra note 81, 78-79.

${ }^{92}$ E.g., Apple filed against Taiwanese High Tech Computer Corp. and its two subsidiaries (one in the United States and one in the British Virgin Islands) in both a federal district court and the ITC. Apple Inc. et al. v. High Tech Computer Corp. et al., D.Del., I:IO-cv-0oı66-RK, complaint filed on Mar. 2, 20I0. The ITC complaint was filed on the same day.

${ }^{93}$ Chien, supra note 81, 71. Chien observed that "perhaps one of [the] most surprising findings is that Section 337 cases have been brought against purely foreign defendants in only a small minority of recent cases (I4 percent)." Id., 87.

${ }^{94}$ Chien, supra note 8I, 87. Compare to 5 percent of district court cases brought solely against foreign defendants in 2004; see Chapter 4, Section 4.I.

${ }^{95}$ Chien, supra note 8I, 87. Compare to Io percent of district court cases brought against both foreign and domestic defendants in 2004; see Chapter 4, Section 4.I.

${ }^{96}$ Chien, supra note 81,87 .
} 
Undeniably, the actions have an impact on foreign companies or activities outside the protecting country because the resulting exclusion orders and the threat of seizures of goods at the border affect the activities of foreign manufacturers, who lose particular markets for their goods.

\subsection{Offers to Sell}

When courts hold that what a defendant claims to be a transit is in fact not a pure transit, the determination may result in a finding of infringement through importation; however, importation was not originally understood as an act of direct infringement-importation as an exclusive right was not included in patent acts in Germany until $198 \mathrm{I}^{97}$ and in the United States until $1994 .{ }^{98}$ Before importation was added as an additional exclusive right, courts often found that infringement in transportation situations was committed through an infringing offer to sell in the protecting country. ${ }^{99}$

If an offer is made in a protecting country to sell a patented invention outside the protecting country, right holders may be able to claim that the offer itself infringes their patent in the protecting country; by doing so they can fight foreign utilization of their patented inventions outside the protecting country. However, such a strategy works against intended or actual sales outside the protecting country only if courts view offers to sell as stand-alone tortious acts of direct infringement and do not require that the sale that is being offered occur in the same country as the offer itself. This section reviews the doctrine of an infringing "offer to sell" and its application in assisting patent holders in fighting the utilization of their inventions outside protecting countries.

Jurisprudence concerning the issue of offers to sell developed during different periods in Germany and the United States and brought remarkably different results. In Germany "offer to sell" was first included in the Patent Act of $1877,{ }^{100}$ and after

\footnotetext{
${ }^{97}$ The German patent acts always included the act of "in Verkehr bringen," which is not only "selling"; it may also be understood as importation. According to Rudolf Kraßer, "[ $\mathrm{t}]$ he importation as such is Inverkehrbringen only for the (foreign) exporter, not for the [German] importer." He admits that the jurisprudence and literature have not been consistent in differentiating between importation and "Inverkehrbringen." KRASSER, Chapter I, note $15,786$.

${ }^{98}$ The 1994 Uruguay Round Agreements Act; TRIPs, Chapter I, note 19, Article 28(I); 35 U.S.C. \$154(a)(I).

${ }^{99}$ The infringing sale can also be found in these scenarios if the method of localization permits them to be captured. See infra Section 3.6. on the issue of localization of a sale.

${ }^{100} \$_{4}$ of the Patent Act of 1877 . The Act used the term "feilhalten," as opposed to the term "anbieten" that was used later. The term "feilhalten," somewhat more limited than "anbieten," was eventually interpreted so broadly
} 
I891 "offer to sell" was expanded to prohibit offers in situations where products that were not themselves patented were made through patented processes. Based on the I89i Act, holders of patents to processes held the same rights to products made through the patented processes as they did to the processes themselves, including the right to offer for sale. ${ }^{101}$

In the United States "offer to sell” was inserted into the U.S. Patent Act in 1994 as part of the implementation of U.S. obligations under the TRIPs Agreement, which in Article 28 includes "offering to sell" among the rights conferred upon a patent holder. "Offer to sell" was also added to Section $27 \mathrm{I}(\mathrm{g})$ of the U.S. Patent Act, ${ }^{102}$ which since 1988 has protected products in the United States that were made abroad by processes patented in the United States. ${ }^{103}$ Prior to the 1994 amendment, offers to sell appeared in U.S. patent-related case law as forms of indirect infringement. ${ }^{104}$ Whether an offer to sell is considered to be an act of direct or indirect infringement is significant because an "offer to sell", if considered only an act of indirect infringement, cannot apply to offers to sell where the sale is to occur abroad; only if an "offer to sell" is an act of direct infringement in the protecting country may an offer that concerns a sale abroad be actionable in the protecting country.

Before it can be determined whether offers made in a protecting country for sales that should or will occur abroad are infringing, it must be clarified what behavior constitutes an offer that will qualify as a patent-infringing act. The choice might fall anywhere on a continuum, with an advertisement on one end and a formal offer as defined by contract law on the other. ${ }^{105}$ The closer the definition is to an

that it overlapped with "anbieten." On the history of the terminology, see Gerhard Schricker, Anbieten als Verletzungstatbestand im Patent- und Urheberrecht, 2004 GRUR INT. 786, 787-88.

${ }^{101} \$_{4}$ of the Patent Act of $189 \mathrm{I}$.

${ }^{102}$ See infra note 13 I.

${ }^{103}$ See also 35 U.S.C. $\$ 154(\mathrm{a})(\mathrm{I})$. The sections have been in the U.S. Patent Act since the 1988 Process Patent Amendments Act but did not mention "offer to sell" until the 1994 Uruguay Round Agreements Act. As Professor Chisum noted, although "[ $t]$ he focus of the legislation is upon foreign activity [(using a process abroad that is patented in the protecting country)], technically, the Process Act has no extraterritorial effect." Chisum, Chapter I, note 173, 607. See also Ajinomoto Co., Inc. v. Archer-Daniels-Midland Co., 228 F.3d I338, I348 (Fed. Cir. 2000) (It "applies to unauthorized actions within the U.S.; it is irrelevant that the product was authorized to be produced outside the U.S."). The German provision also protects products made by patented processes not only in Germany but also abroad. See, e.g., Diazepam, Landgericht Düsseldorf, 4 O 99/68, Sept. I8, 1969, 1970 GRUR 550 ("Offer to sell and use of [an] ingredient in the [protecting country] is a patent infringement even when it [was] produced [by the patented process] abroad." Id., $55 \mathrm{I}$.). On the relevant provision of the Paris Convention, see Bodenhausen, Chapter I, note 68, 85.

${ }^{104}$ See infra Section 3.5.

${ }^{105}$ For a discussion of the various definitions of an offer to sell see Lucas S. Osborn, Deconstructing an "Offer to Sell" in the Patent Infringement Context, draft paper, on file with the author, i $4 \mathrm{ff}$. 
advertisement, the better for any patent holder, including a patent holder who attacks an offer that concerns a sale abroad.

German courts decided early on that an offer to sell for purposes of the Patent Act should not be defined in terms of contract law; instead, the courts have used economic criteria to assess whether particular conduct constitutes an offer to sell. ${ }^{106}$ Therefore, negotiations of an individual contract were not the only activity that was deemed to constitute an infringing offer to sell; ${ }^{107}$ showing marketing materials to potential buyers was also viewed as an infringing offer to sell. ${ }^{108}$ For instance, the Düsseldorf Landgericht noted that acts of a Chinese company that exhibited infringing products at the CeBIT international fair in Hannover would be considered infringing offers to sell. ${ }^{109}$ Although German courts recognize an exception for advertising at "general exhibitions" ("allgemein Leistungsschau”), which are exhibitions designed to "provide the expert circles and the public an overview of the state of the field, but do [...] not have a character of a sale exhibition or a fair," ${ }^{110}$ courts have construed this term narrowly. In the case of CeBit, the Düsseldorf Landgericht declined to extend the exception to CeBIT because CeBIT, as "the largest computer and electronics fair in the world[,] provides for establishment of contacts and making business," 111 and therefore, exhibiting an infringing product at such an event is an infringing offer to sell.

In the United States after the 1994 Act introduced the "offer to sell," and as the first cases on the issue appeared in courts, commentators began to debate the proper definition of an "offer to sell." Some commentators advocated a definition of infringing conduct in strict contract law terms, reasoning that economic considerations dictated a limited approach. Others argued for a broader construction of the term that would "extend $[. .$.$] beyond contractual offers" 112$ because such an interpretation

\footnotetext{
${ }^{106}$ E.g., Kupplung für optische Geräte, Bundesgerichtshof, X ZR 179/02, Sept. 16, 2003; Thermocycler, Oberlandesgericht Düsseldorf, 2 U 58/05, Dec. 21, 2006, 2007 GRUR-RR 259 ("The term 'offer' used in \$9 [of the Patent Act] must be understood in the economic sense and does not coincide with the legal term of a contract offer." Id., 26I.). See also Schricker, supra note IOI, 787.

${ }^{107}$ Kreuzbodenventilsäcke, Bundesgerichtshof, I ZR 109/58, Mar. 29, 1960, 1960 GRUR 423.

${ }^{108}$ E.g., Kupplung für optische Geräte, supra note 106; Reichsgericht, I 137/33, Jan. 13, 1934, RGZ 29, 173; Zeitlagenmultiplexverfahren, Landgericht Düsseldorf, 4a O 124/05, Feb. 13, 2007.

${ }^{109}$ Zeitlagenmultiplexverfahren, supra note 108.

${ }^{110}$ Zeitlagenmultiplexverfahren, supra note 108; Heißläuferdetektor, Bundesgerichtshof, X ZR 52/67, Dec. I8, 1969, 1970 GRUR 358. "An exhibition and presentation at a 'Leistungsschau' is only then an 'industrial use' within the meaning of $\$ 6(\mathrm{I})$ of the Patent Act when the exhibitor pursues a mercantile purpose." Id., 360 .

${ }^{111}$ Zeitlagenmultiplexverfahren, supra note 108.

${ }^{112}$ Edwin D. Garlepp, An Analysis of the Patentee's New Exclusive Right to "Offer to Sell," 8 I J. Pat. \& Trademark OfF. Soc'y 315, 319 (1999).
} 
would serve better the needs of patent holders ${ }^{113}$ and reflect " $[t]$ he history of the GATT implementing legislation," ${ }^{114}$ which led to Congress's intent "to significantly strengthen patent law." 115

The U.S. Court of Appeals for the Federal Circuit first addressed the offer to sell problem in 1998 in 3 D Systems, Inc. v. Aarotech Laboratories, Inc. ${ }^{116}$ in the context of a discussion of personal jurisdiction. For the purposes of personal jurisdiction, the court adopted an approach broader than that of contract law and found that "price quotation letters [could] be regarded as 'offer[s] to sell."'117 Some thirteen months later the court had its first opportunity to consider the term in a decision on the merits in Rotec Indus., Inc. v. Mitsubishi Corp. ${ }^{118}$ The court derived guidance from a then-recent Supreme Court decision on the "on sale" bar to patentability; ${ }^{119}$ because the Supreme Court construed a "commercial offer for sale" in contract law terms ${ }^{120}$ the Circuit Court concluded that the definition of an "offer to sell" for infringement purposes should be guided by "the norms of traditional contractual analysis."121 Since in Rotec the defendant's communication with the potential purchaser did not comply with the definition of an offer in contract law the court found no "offer to sell" within the meaning of the Patent Act. ${ }^{122}$

The current definition of "offer to sell" used by the U.S. Court of Appeals for the Federal Circuit thus differs dramatically from the definition used in German courts; as a result a much wider range of acts fall within the scope of an infringing "offer to sell” in Germany than in the United States. ${ }^{123}$ The rigid approach taken by the

\footnotetext{
${ }^{113}$ Garlepp, supra note i12, 319.

${ }^{114}$ Robert Ryan Morishita, Patent Infringement After GATT: What Is an Offer to Sell?, 1997 UTAH L. REv. 905 , 912.

${ }^{115}$ Morishita, supra note II 4. For a review of the relevant legislative history, see id., 912-I3.

${ }_{316}^{11}$ D Systems, Inc. v. Aarotech Laboratories, Inc., I60 F.3d 1373 (Fed. Cir. 1998).

${ }^{117} I d$., I379. The court explicitly declined to "import the authority construing the 'on sale' bar."

${ }^{118}$ Rotec Indus., Inc. v. Mitsubishi Corp., 215 F.3d 1246 (Fed. Cir. 2000).

${ }^{119}$ Pfaff v. Wells Electronics, Inc., 525 U.S. 55 (1998). "On sale bar" is a term that describes a bar to patentability presented by a sale in the United States "more than one year prior to the date of the application for patent in the United States.” 35 U.S.C. \$102(b).

${ }^{120}$ Pfaff v. Wells Electronics, Inc., 525 U.S. 55, 67 (1998). The Supreme Court looked at an acceptance of the purchase order (clearly a contract law concept) to conclude that "the sale was commercial rather than experimental in character." $I d$.

${ }^{121}$ Rotec Indus., Inc. v. Mitsubishi Corp., 215 F.3d 1246, 1254-55 (Fed. Cir. 2000). See also Transocean Offshore Deepwater Drilling, Inc. v. Maersk Contractors USA, Inc., 617 F.3d 1296, 1308 (Fed. Cir. 2010).

${ }^{122}$ The court used the definition of an offer in the Restatement (Second) of Contracts, \$24 (1979): "An offer is the manifestation of willingness to enter into a bargain, so made as to justify another person in understanding that his assent to that bargain is invited and will conclude it." Rotec Indus., Inc. v. Mitsubishi Corp., 215 F.3d I246, I257 (Fed. Cir. 2000).

${ }^{123}$ The court in Rotec commented on the situation in the United Kingdom where "the common law of contract does not limit the meaning of 'offer for sale' in the context of patent infringement." Rotec Indus., Inc. v. Mitsubishi Corp., 215 F.3d 1246, 1253 (Fed. Cir. 2000).
} 
U.S. Court of Appeals for the Federal Circuit to the interpretation of an "offer" contrasts with the liberal approach that U.S. courts have adopted in their interpretation of a "sale"; the definition of a sale becomes important when the place of an infringing sale needs to be determined, as discussed below in Section 3.6. Although the interpretation by the U.S. Court of Appeals for the Federal Circuit of an infringing "offer" is quite limited and is likely to have an adverse impact on patent holders' abilities to reach those who utilize their inventions anywhere, what is even more important for evaluating the usability of the "offer to sell" provision for fighting conduct outside a protecting country is whether patent holders may use an "offer to sell" to capture an offer that concerns a sale outside the protecting country. In other words, would an offer made in the United States be infringing if it concerned a sale of goods that should occur in China?

In Germany courts have held that an offer to sell is infringing regardless of where the eventual sale is intended to occur or where it actually occurs. For an offer to sell that is made in Germany to be infringing, goods at issue need not be present in Germany at the time of the offer or at any later time, or even be intended to ever enter Germany. ${ }^{124}$ Therefore, even offers to sell made at trade fairs in Germany with the intent for the sale to take place outside Germany were found sufficient acts of infringement. ${ }^{125}$ An offer made in Germany to sell goods abroad resulted in a finding of an infringing offer to sell in Germany even when the goods were marked clearly as "for sale outside Germany." 126

It is remarkable that the elements controlling whether there is an infringing offer to sell are the opposite in the United States and Germany; in the United States the controlling element is the location of the sale, while in Germany it is the location of the offer itself. Under the current interpretation that the U.S. Court of Appeals for the Federal Circuit pronounced in Transocean Offshore Deepwater Drilling, Inc. v. Maersk Contractors USA, Inc., ${ }^{127}$ "the location of the contemplated sale controls

\footnotetext{
${ }^{124}$ Reichsgericht, I 137/33, Jan. I3, 1934, RGZ 29, I73; Kreuzbodenventilsäcke, supra note 107.

${ }^{125}$ Messeangebot ins Ausland I, Landgericht München I, 2I O 642I/OI, June 23, 2004, 5 ENTSCHEIDUNGEN DER InSTANZGERICHTE ZUM ReCHT DES GEISTIGEN EIgENTUMS I3 (2004); appeal denied in Messeangebot ins Ausland I, Oberlandesgericht München, 6 W 2048/04, Sept. 16, 2004. The appeals court rejected the opinion of Jochen Pagenberg that the offer to sell, even though an independent tort, should be interpreted in a restrictive manner. Id. See Jochen Pagenberg, Ausstellen und Anbieten auf internationalen Messen-eine Verletzung inländischer gewerblicher Schutzrechte?, 1983 GRUR INT. 560.

${ }^{126}$ Messeangebot ins Ausland I, supra note 125. See also Infrarot-Messgerät, Landgericht Düsseldorf, 4 b O $388 / 0_{3}$,

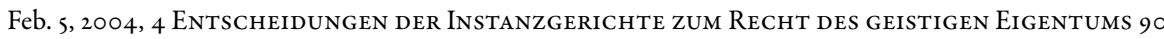
(2003). In this case the device was exported from Germany, rebuilt in the United States and labeled as "assembled in USA with parts from Germany." The court referred to Kreuzbodenventilsäcke when it decided that there was also an infringing offer to sell. $I d$.

${ }^{127}$ Transocean Offshore Deepwater Drilling, Inc. v. Maersk Contractors USA, Inc., 617 F.3d 1296 (Fed. Cir. 2010).
} 
whether there is an offer to sell within the United States," 28 which means that an offer made anywhere in the world for a sale in the United States will be infringing under U.S. patent law, but an offer made in the United States for a sale outside the United States will not constitute a patent infringing act. ${ }^{129}$

Prior to the 2010 decision in Transocean Offshore, the interpretation of the U.S. statutory language was unclear, and no relevant legislative history existed that would shed light on the problem. ${ }^{130}$ When the "offer to sell" concept was introduced into the Patent Act in $1994^{131}$ Congress omitted any explanation as to what the subsequent phrase "within the United States" modified. ${ }^{132}$ Three options appeared possible: the offer to sell itself must be made in the United States but the place of sale does not matter, ${ }^{133}$ the offer to sell can be made anywhere but the sale must occur or be intended to occur in the United States, ${ }^{134}$ or both the offer to sell must occur and the sale must occur or be intended to occur in the United States. ${ }^{135}$ Commentators disagreed on the correct interpretation of the ambiguous language of the Act; ${ }^{136}$ one commentator suggested that "a reading that requires only that an offer be within the United States to infringe $\$ 27 \mathrm{I}(\mathrm{a})$ may be an impermissible expansion of the territorial scope of U.S. patent laws." 137

${ }^{128}$ Id., 1309 .

${ }^{129}$ Although the holding in the case refers only to the specific scenario in which two U.S. companies negotiate abroad a contract for performance in the United States (Transocean Offshore Deepwater Drilling, Inc. v. Maersk Contractors USA, Inc., 617 F.3d I296, 1310 (Fed. Cir. 2010)), dicta suggest that the rule will apply even if non-U.S. companies are involved: "The focus should not be on the location of the offer, but rather the location of the future sale that would occur pursuant to the offer." Id., I309.

${ }^{130}$ Even if it considered offers to sell, pre-1994 case law would not be of assistance because it had only considered offers to sell in the context of indirect infringement. See infra Section 3.5 for a discussion of the territorial scope of provisions on indirect infringement.

131 "Offer to sell” was added in 35 U.S.C. \$27 I in paragraphs (a), (c), (e), and (g).

${ }^{132}$ In paragraphs (a) and (g) the words "within the United States" remained from the previous versions of the law; however, in (c) and (e) the words "within the United States" were added by the 1994 Act. It has been debated what, if anything, the insertion of "within the United States" should mean; however, a review of the 1994 Act reveals that the legislator probably wished only to make the wording in all four paragraphs consistent and used the wording from paragraph (a) for this purpose. Professor Chisum noted that " $t$ ] here appear[ed] to be no policy reason for restricting Section $27 \mathrm{I}(\mathrm{c})$ in this fashion. The change may have been a grammatical indiscretion." Chisum, Chapter I, note $173,615$.

${ }^{133}$ Garlepp, supra note i12, 325 .

${ }^{134}$ Holbrook, Territoriality, Chapter I, note 5, 728.

${ }^{135}$ Garlepp, supra note i12, 325 .

136 "With legislative history silent, an interpretation based solely on the mechanics of the English language may indicate Congressional intent to adopt the broader reading." Garlepp, supra note 112, 325. "Given the lack of guidance in the legislative history and the ambiguous statutory language, the presumption should not be conclusive as to the extraterritorial reach of 'offers to sell,' and the appropriate scope merits further discussion." Holbrook, Territoriality, Chapter I, note 5, 731. See also Chisum, Chapter I, note 173, 615.

${ }^{137}$ Garlepp, supra note 112, 326. 
In 2000 Rotec offered an opportunity to clarify whether the sale needed to occur or be intended to occur in the United States, but the majority in that case avoided the issue; only Judge Newman in her concurring opinion addressed the issue, opining that only if the intended sale would infringe a U.S. patent could the offer to sell be infringing. ${ }^{138}$ She reasoned that the statutory requirement that the offered "sale will occur before the expiration of the term of the patent" ${ }^{139}$ meant that the patent must be valid under U.S. law at the time of the intended sale, and therefore the sale must have been envisaged in the United States because it was only in the United States where a U.S. patent could be valid. ${ }^{140}$

In Transocean Offshore ${ }^{141}$ the U.S. Court of Appeals for the Federal Circuit explained that because the place of the intended sale is controlling, an offer made in Norway for delivery and use in the United States will infringe a U.S. patent. ${ }^{142}$ This interpretation finally provides needed guidance to district courts, which split in their decisions on the issue prior to Transocean Offshore; some courts held that the sale need not occur or be intended to occur in the United States, while other courts insisted that the sale must occur or be intended to occur in the United States. ${ }^{143}$ For instance, in Wesley Jessen Corp. v. Bausch \& Lomb, Inc. ${ }^{144}$ the U.S. District Court for the District of Delaware noted that " $[t]$ he geographic location and physical destination of the subject matter of the 'offer' appear to be immaterial to the analysis, so long as the 'offer' was made in the United States." ${ }^{45}$ The court decided that "the 'sale' contemplated by the 'offer to sell' need not take place in the United States or be intended to take place in the United States for there to be infringement because of the 'offer to sell."'146 Other courts disagreed; for instance, in Semiconductor Energy Laboratory Co., Ltd. v. Chi Mei Optoelectronics Corp. ${ }^{147}$ the U.S. District Court for

\footnotetext{
${ }^{138}$ Rotec Indus., Inc. v. Mitsubishi Corp., 215 F.3d I246, I258-60 (Fed. Cir. 2000).

${ }_{139} 35$ U.S.C. $\$ 271(\mathrm{i})$.

${ }^{140} 35$ U.S.C. $\$ 27 \mathrm{I}(\mathrm{i})$ does not actually specify that the patent must be a U.S. patent, an omission that has generated debate over whether the Act could have contemplated a foreign patent as well. Holbrook, Territoriality, Chapter I, note 5, $748 \mathrm{ff}$.

${ }^{141}$ Transocean Offshore Deepwater Drilling, Inc. v. Maersk Contractors USA, Inc., 617 F.3d 1296 (Fed. Cir. 2010).

${ }_{142}$ "In order for an offer to sell to constitute infringement, the offer must be to sell a patented invention within the United States." Id., I309.

${ }^{143}$ For a helpful recent overview of various district court decisions, see, e.g., Transocean Offshore Deepwater Drilling, Inc. v. Stena Drilling Ltd., 659 F.Supp.2d 790 (S.D.Tex. 2009).

${ }^{144}$ Wesley Jessen Corp. v. Bausch \& Lomb, Inc., 256 F.Supp.2d 228 (D. Del. 2003).

${ }^{145} I d ., 233$.

${ }^{146} I d ., 234$.

${ }^{147}$ Semiconductor Energy Laboratory Co., Ltd. v. Chi Mei Optoelectronics Corp., 53I F.Supp.2d 1084 (N.D.Cal. 2007).
} 
the Northern District of California emphasized "the strong presumption against extraterritorial application," and decided that "an 'offer of sale' may constitute direct infringement only if the sale is intended to take place within the United States."148

The requirement that a sale must occur or be intended to occur in the United States for the offer to sell to be infringing significantly limits the usefulness of the prohibition against an "offer to sell" in any fight in the United States against foreign utilization of patented inventions. By contrast, the broad interpretation that German courts attach to offers to sell and the fact that the sale need not occur in Germany or be intended to occur in Germany enables holders of German patents to reach those who engage in acts leading to foreign utilization of their inventions. In the United States the utility of the offer to sell in fighting foreign exploitations of the invention will depend on where the act of selling is localized; this problem is discussed below in Section 3.6.

\subsection{Inventions Assembled Abroad from Components from a Protecting Country}

Another means of stopping or curtailing the utilization of an invention abroad is to prevent exportation from a protecting country of components that are to be used in assembling the patented product abroad. If patent holders can prevent the exportation of components from the protecting country, they will likely have a significant impact on possible utilization of the assembled product abroad. Often cases involving these facts include situations in which manufacturers or suppliers of components in a protecting country realize that they would infringe a patent if they manufactured or supplied the product fully assembled; therefore, they try to circumvent the patent protection by avoiding the final assembly and manufacturing, and supplying only disassembled components of the final product.

In Germany and the United States the mechanisms to fight the supplying of parts developed in different manners but arrived at a similar, though not identical, result. German courts were successful very early at prohibiting conduct involving component supply by applying the existing doctrines of direct infringement through manufacture and offer to sell. As the following paragraphs show, a finding of intent on the part of an alleged infringer was the key to these cases. In the United States the landmark decision of Deepsouth Packing Co. v. Laitram Corp. ${ }^{149}$ revealed that U.S. case

${ }^{148} I d$., IIII.

${ }^{149}$ Deepsouth Packing Co. v. Laitram Corp., 406 U.S. 518 (1972). 
law would not extend the then-current doctrines to cover scenarios involving components supplied abroad; the realization that such a loophole existed in U.S. law led to legislative intervention that introduced new forms of direct infringement specifically tailored to address component situations.

In Germany direct infringements through manufacture or offer to sell have been found when there was knowledge on the part of the infringer about the subsequent use of the components. For instance, in 1888 the Reichsgericht held that infringement would be found whenever a defendant intended for noninfringing components to be assembled outside Germany into a product that would have infringed a German patent if it were assembled in Germany. ${ }^{150}$ It is interesting that in these scenarios the intent of the alleged infringer matters, because normally no intent is required for a finding of direct patent infringement.

The intent of an infringer may be apparent either from acts performed by the infringer (such as an offer to sell accompanied by information about how to assemble the components abroad) or from the nature of the components. The fact that the components at issue are not "neutral"151 but "are exclusively suitable to be assembled into the product"152 suggests that when dealing with the components the alleged infringer must have been aware of their singular use. These "specific components"153 in the German patent law correspond to what the U.S. Patent Act calls "material part $[s]$ of the invention," which are defined as parts "especially made or especially adapted for use in an infringement of [the] patent." ${ }^{154}$ The U.S. Patent Act further explains that "staple article[s] or commodit[ies] of commerce suitable for substantial noninfringing use" are not "material parts" of an invention. ${ }^{155}$ As long as the "specific components" are at issue, German courts find direct infringement; for "neutral components" they require that specific knowledge of the intended use of the components be proven. ${ }^{156}$

\footnotetext{
${ }^{150}$ Reichsgericht, I 86/88, May 5, I888, RGZ 22, I65; Reimer, Patentverletzung, Chapter I, note 6, 88.

${ }^{151}$ The Reichsgericht in an 1897 decision characterized "neutral components" as parts that were of general purpose, could be generally replaced, and therefore did not "embody any special value." Reichsgericht, I 98/97, Sept. 18, 1897, RGZ 22, 78 .

${ }^{152}$ Diffusor, Landgericht Düsseldorf, 6 Entscheidungen DER InSTANZgerichte zum Recht DES GEISTIGen Eigentums 130 (2005); Isolierglasscheiben II, Landgericht Düsseldorf, $4 \mathrm{aO}$ 220/07, Aug. 5, 2008.

153 "Die erfindungsfunktionell individualisierte Teile."

${ }^{154} 35$ U.S.C. $\$ 27 \mathrm{I}(\mathrm{c}), \$ 27 \mathrm{I}(\mathrm{f})(2)$.

${ }^{155} 35$ U.S.C. $\$ 27 \mathrm{I}(\mathrm{c}), \$_{27} \mathrm{I}(\mathrm{f})(2)$. In I87 I the Connecticut District Court in Wallace v. Holmes considered a person to be indirectly liable for patent infringement; what was dispositive of the case was "the certain knowledge" by the defendant that the unpatented components were "to be used, as they [could] only be used," in the assembled product. Wallace v. Holmes, 29 F. Cas. 74, 80 (D. Conn. 1871).

${ }^{156}$ In Verbolzung the Düsseldorf Oberlandesgericht found no direct infringement because no manufacture or use was proven that would indicate that the components were specifically prepared to be used in
} 
An 1897 case illustrates the approach taken by German courts with regard to the manufacture of components intended for foreign assembly; the Reichsgericht in the case held that the defendant infringed when it manufactured components in Germany and shipped them to Denmark and Switzerland for assembly. ${ }^{157}$ The court reasoned that "manufacturing of a patent encompasses the entire activity necessary for a production of the product from its very beginning"; 158 the court rejected as against the meaning of the statutory text and purpose of the law the argument that the term "manufacturing" would encompass only "the activities immediately leading up to the completion" 159 of the product. The court suggested that it was indefensible to define the place of manufacture as only the place of assembly abroad; such a narrow definition would permit the manufacture of components in Germany in preparation for assembly of the final product abroad where the invention was not protected. ${ }^{160}$

The same conclusion was reached in other German cases concerning the manufacture of components. For instance, in 1935 the Reichsgericht found infringement where the defendant manufactured two parts of a patented invention that were individually noninfringing; the defendant exported the parts abroad where customers could easily assemble them and use the invention in the form in which it was patented in Germany. ${ }^{161}$ In a 2004 case the Düsseldorf Landgericht held that it was an infringement in the form of manufacture when the defendant manufactured a product in Germany that the defendant then sold to a customer abroad in a noninfringing form but with the understanding that the defendant would provide instructions and a component to convert the product abroad into a product corresponding to the device patented in Germany. ${ }^{162}$ Although one commentator recently expressed doubts "whether the broad interpretation of the term 'making' favored by German courts in the past [could] still be applied," ${ }^{163}$ for now the law in Germany

infringing products. The defendant supplied one component abroad but did not do so with the intent that the component be combined with another component (which happened to be supplied by the plaintiff-the exclusive license holder) into the final product that corresponded to the German patented invention. Verbolzung, Oberlandesgericht Düsseldorf, 2 U 133/61, Jan. II, 1963, 1964 GRUR 203.

${ }^{157}$ Reichsgericht, I 98/97, Sept. 18, 1897, RGZ 22, 78.

${ }^{158} I d$., 79 .

${ }^{159} I d ., 79$.

${ }^{160} I d ., 8 \circ$.

${ }^{161}$ Stabeisenbiegevorrichtung, Reichsgericht, Aug. 30, 1935, 1936 GRUR 236; see also Stauder, Patent Infringement, supra note 8, 495-96. See also Dia-Rämchen V, Bundesgerichtshof, X ZR 4/65, July 14, 1970, 1971 GRUR 78, 80 (in a purely domestic context but summarizing the relevant jurisprudence).

${ }^{162}$ Infrarot-Messgerät, supra note 126.

${ }^{163}$ Rainer Moufang, The Extraterritorial Reach of Patent Law, in Patents and Technological Progess in a Globalized World-Liber Amicorum Joseph Straus 6oi, 607 (Wolrad Prinz zu Waldeck und 
remains that manufacture of components in Germany for assembly abroad is patent infringing. ${ }^{164}$

In addition to the manufacture of components, offers to sell components for assembly abroad have also been considered acts of direct infringement actionable under the German Patent Act; again, the defendant's knowledge of the intended use of the components was dispositive of the issue. For instance, in Kreuzbodenventilsäcke ${ }^{165}$ the Bundesgerichtshof found infringement where the manufacturer offered to deliver noninfringing components abroad with the promise that it would send its own technicians to set up the product abroad so that it would correspond to the invention patented in Germany. The court agreed with plaintiff's contention that the defendant engaged in an infringing offer to sell when it offered to supply the noninfringing components and explained that "an offer to sell is infringing when it is obvious that the recipient of the offer is supposed to receive the product in its patent infringing form." 166

When the United States extended the protection of the patent law to "specific parts" - "material parts of inventions" - in 1952, it limited the protection to acts of sale; "making" was left out of the provision. However, and more importantly, the provision was drafted to codify existing case law on contributory infringement, ${ }^{167}$ which meant that it would cover only acts of indirect infringement related to an act of direct infringement committed in the United States; ${ }^{168}$ it was not drafted to apply to instances in which the related assembly occurred outside the United States. ${ }^{169}$ For this reason the provision was of no assistance in the landmark case of Deepsouth, which was decided by the U.S. Supreme Court in 1972 and which prompted a legislative response.

In Deepsouth, Laitram held patents on a shrimp deveining machine that Deepsouth allegedly infringed; Deepsouth argued that it should be permitted to manufacture components of the machine in the United States and sell them to

\footnotetext{
Pyrmont, Martin J. Adelman, Robert Brauneis, Josef Drexl, \& Ralph Nack eds., 2009). “Even in situations where the facts indicate that the alleged infringer actively induces or even controls the ultimate step in the process of manufacture carried out abroad, it cannot be neglected that it is outside the territory of production where this ultimate step takes place, i.e. where the patented product is made." Id., 607-08.

${ }^{164}$ Rudolf Busse, Patentgesetz 222 (1999).

${ }^{165}$ Kreuzbodenventilsäcke, supra note 107.

${ }^{166} I d$.

${ }^{167}$ For a further discussion of acts of indirect infringement under the U.S. Patent Act, see infra Section 3.5.

${ }^{168}$ Wallace v. Holmes, 29 F. Cas. 74 (D. Conn. I87I).

${ }^{169}$ See infra Section 3.5 for a discussion of provision 35 U.S.C. $\$ 27 \mathrm{I}(\mathrm{c})$.
} 
customers abroad for assembly of the machines outside the United States. ${ }^{170}$ The U.S. Supreme Court rejected the holding of the U.S. Court of Appeals for the Fifth Circuit that the "substantial manufacture of the constituent parts of [a] machine" constituted an act of direct infringement ${ }^{171}$ - a holding by the Circuit Court that had matched the German approach. In rejecting the argument that direct infringement had occurred, the Supreme Court reiterated its earlier position that "a combination patent protects only against the operable assembly of the whole and not the manufacture of its parts." 172 The Court was divided in its decision-four Justices filed a dissenting opinion - and, not surprisingly, a legislative response overruled the decision in 1984 .

The 1984 amendment to the U.S. Patent Act introduced two new forms of direct patent infringement; ${ }^{173}$ one focuses on "material parts" of inventions, and the second covers "non-material parts" of inventions, or what German courts call "neutral parts." Section $27 \mathrm{I}(\mathrm{f})(2)$ states that a direct infringement occurs when a component that is a material part of the invention is supplied or caused to be supplied "in or from the United States" with knowledge that it is a material part of an invention and with the intent that the component be combined into a final assembled product outside the United States. ${ }^{174}$ Section $27 \mathrm{I}(\mathrm{f})(\mathrm{I})$ covers "non-material parts" and considers as a direct infringer one who "supplies or causes to be supplied in or from the United States all or a substantial portion of the components [. . .] in such manner as to actively induce the combination of such components outside the United States." 175

Notwithstanding the differing approaches of their legislative solutions, the German and U.S. results are largely overlapping. German law, however, has broader scope because it covers acts that could be described as being in preparation for "supplying or causing to supply"-it covers the manufacture of components and offers to sell when the acts are accompanied by knowledge that components will be assembled, but an act of actual supplying abroad is not required for a finding of infringement. By contrast, Section 27I of the U.S. Patent Act does not prohibit the manufacture of components in the United States or offers made in the United States

\footnotetext{
${ }^{170}$ Deepsouth Packing Co. v. Laitram Corp., 406 U.S. 518, 523 (1972). As the Supreme Court noted in a footnote, "Deepsouth [was] entirely straightforward in indicating that its course of conduct [was] motivated by a desire to avoid patent infringement." Id.

${ }^{171}$ Laitram Corp. v. Deepsouth Packing Co., 443 F.2d 936, 939 ( 5 th Cir. 1971).

${ }^{172}$ Deepsouth Packing Co. v. Laitram Corp., 406 U.S. 518,528 (1972).

${ }^{173} 35$ U.S.C. $\$ 27 \mathrm{I}(\mathrm{f})(2)$ does not incorporate contributory infringement; it is a new category of direct infringement. Waymark Corp. v. Porta Sys. Corp., 245 F.3d 1364, 1460 (Fed. Cir. 2001).

${ }^{174} 35$ U.S.C. $\$ 27 \mathrm{I}(\mathrm{f})(2)$. The provision was added in 1984.

${ }^{175}{ }_{35}$ U.S.C. $\$ 27 \mathrm{I}(\mathrm{f})(\mathrm{I})$. The provision was added in 1984 . See infra Section 3.5 for a discussion of the requirement of intent under the U.S. Patent Act.
} 
to sell components abroad; ${ }^{176}$ it is questionable whether "supplying or causing to supply" components under the U.S. Patent Act could cover all acts involved in "making, offering to sell, selling, using or importing" components that may be actionable under the German Patent Act.

\subsection{Acts Abroad Contributing to Infringements in the Protecting Country}

The previous sections discussed scenarios in which acts in the protecting country led to further utilization of an invention abroad. The opposite scenario involves an act abroad (offer to sell, sale, or export of an invention or its components) that is directed at the protecting country and leads to further acts in the protecting country (importation, use, further offer of sale, sale) that infringe a patent. Although in such situations it should be possible to target direct infringers in the protecting country (importers, distributors, end users), patent holders may sometimes attempt to attack abroad "at the source"; such a tactic may be motivated by patent holders' hopes that attacking at the source will significantly reduce future infringements that are or may be unrelated to the current channels of distribution. Additionally, patent holders may pursue actors abroad because it is impractical to target direct infringers in the protecting country; direct infringers might lack sufficient assets or be difficult to identify, as is typically the case with end users. ${ }^{177}$ Alternatively, there could be tactical reasons to attempt to pull a party acting abroad into the litigation in the particular protecting country; it might be more difficult to attack "the source" abroad, in the country where the acts were committed, or it might be inconvenient for the patent holder or even impossible if he lacks a parallel patent in the other country.

Sometimes defining the location of the acts will help to fight such acts abroad; if the acts can be localized in multiple locations, including in the protecting country, the conditions of direct infringement may be satisfied in the protecting country. ${ }^{178}$ But even if the acts can only be localized abroad, the doctrine of indirect infringement ${ }^{179}$ may still allow courts to adjudicate these acts-as long as the doctrine extends to the acts of indirect infringement committed abroad. While it is established law that indirect infringement requires related acts of direct infringement in

\footnotetext{
${ }^{176} 35$ U.S.C. $\$ 27 \mathrm{I}(\mathrm{c})$ and $(\mathrm{f})$.

${ }^{177}$ Sometimes there may be public relations reasons for not targeting end users.

${ }^{178}$ See infra Section 3.6 for a discussion of localization of infringing acts.

179 "Mittelbare Patentverletzung" in German.
} 
the protecting country, ${ }^{180}$ the answers may vary to the question of where the acts of indirect infringement must occur-whether the acts of indirect infringement must also be committed in the protecting country, or whether they can occur abroad as long as the related acts of direct infringement can be localized in the protecting country.

Prior to the adoption of legislation on indirect patent infringement, doctrines had existed in both Germany and the United States that covered some of the acts that were committed abroad; before the 1952 amendment to the U.S. Patent Act, which added two forms of indirect infringement, the tort law concept of aiding and abetting was applied to circumscribe the behavior of those "who did not commit an act of direct infringement but rather enabled others to do so." ${ }^{181}$ In Germany the general doctrines of participating in and aiding and abetting a tortious activity ${ }^{182}$ covered acts committed abroad, and the doctrines continue to be used today, even after a specific provision on indirect infringement was included in the German Patent Act.

The provisions on indirect infringement added to the U.S. Patent Act in 1952 divided indirect infringements into inducement under Section $27 \mathrm{I}$ (b) and contributory infringement under Section $27 \mathrm{I}(\mathrm{c}) .{ }^{183}$ The legislative treatment of inducement tracked cases in which "efforts to induce infringement" were treated "as evidence supporting the requisite affirmative intent for a case of [indirect] infringement." 184 The fact that the provision does not explicitly include the requirement of "knowing" created uncertainty about the requirement of intent; the U.S. Supreme Court clarified the requirement of intent in Global-Tech Appliances, Inc. v. SEB, S. A. by ruling that Section $27 \mathrm{I}(\mathrm{b})$ "requires knowledge that the induced acts constitute patent

\footnotetext{
${ }^{180}$ For the requirement of direct infringement for a finding of inducement in the United States, see Joy Techs., Inc. v. Flakt, Inc., 6 F.3d 770, 774 (Fed. Cir. 1993); Read Corp. v. Powerscreen of America, Inc., 44 Fed. Appx. 502 (Fed. Cir. 2002); Ricoh Company, Ltd. v. Quanta Computer, Inc., 550 F.3d 1325, 1341-43 (Fed. Cir. 2009). For the requirement of direct infringement for a finding of contributory infringement in the United States, see Aro Manufacturing Co. v. Convertible Top Replacement Co., 365 U.S. 366 (1961). For the requirement of a finding of intent of direct infringement for indirect infringement in Germany, see Funkubr II, Bundesgerichtshof, X ZR 53/04, Jan. 30, 2007; Flügelradzähler, Bundesgerichtshof, X ZR 48/03, May 4, 2004, BGHZ 159, 76, 2004 GRUR 758. But cf. Deckenheizung, Bundesgerichtshof, X ZR 153/03, June I3, 2006, 2006 GRUR 839, 84I.

${ }^{181}$ Chisum, Chapter I, note 173, 614-15. See, e.g., Wallace v. Holmes, 29 F. Cas. 74 (D. Conn. 1871).

${ }^{182}$ Civil Code, $\$ 830$.

183 "Before 1952 , both the conduct now covered by 35 U.S.C. $\$ 27 \mathrm{I}(\mathrm{b})$ (inducement of infringement) and the conduct now addressed by 35 U.S.C. \$27I (c) (sale of a component of a patented invention) were viewed as falling within the overarching concept of 'contributory infringement." Global-Tech Appliances, Inc. v. SEB, S.A., I3I S.Ct. 2060, 2066 (2011).

${ }^{184}$ Mark Lemley, Inducing Patent Infringement, 39 U.C. DAvis L. Rev. 225, 227 (2005). On the interpretation of the terms "inducement," "active," and the issue of the required intent in $27 \mathrm{I}(\mathrm{b})$ see id., 228-4I.
} 
infringement," 185 and this requirement may be satisfied by an infringer's willful blindness. ${ }^{186}$

The treatment of contributory infringement under Section $27 \mathrm{I}(\mathrm{c})$ of the U.S. Patent Act followed cases that involved components of patented inventions where the nature of the components alone evidenced intent of subsequent direct infringement. A contributory infringer is one who "offers to sell or sells within the United States or imports into the United States a component" of a patented invention knowing that the component is "a material part of the invention." 187

An act of inducement may be committed outside the U.S. territory, ${ }^{188}$ and given the broad language of Section $27 \mathrm{I}(\mathrm{b})$, the possibility exists that a wide variety of acts abroad may be viewed as inducement of patent infringement. ${ }^{189}$ The provision on contributory infringement in Section $27 \mathrm{I}(\mathrm{c})$, however, applies only to acts of offers to sell or sales "within the United States" and importation "into the United States."190 Language that was intended to territorially limit the scope of the contributory infringement provision was added to the Act in 1994, and it prevents use of the provision against acts committed abroad. Before 1994 courts had found that conduct outside the United States could lead to contributory liability under the provision; since 1994 the provision has been limited solely to conduct in the United States. Of course, the recent interpretation by the U.S. Court of Appeals for the Federal Circuit in Transocean Offshore ${ }^{191}$ of "offer to sell" in the context of Section $27 \mathrm{I}$ (a) opens the door to the possibility that the "offer to sell" under Section $27 \mathrm{I}$ (c) could also encompass offers made outside the United States for sale of components in the United States. ${ }^{192}$

\footnotetext{
${ }^{185}$ Global-Tech Appliances, Inc. v. SEB, S.A., I3I S.Ct. 2060, 2068 (201I).

${ }^{186} \mathrm{Id}$.

${ }^{187} \mathrm{~A}$ "material part of the invention" is a part "made or especially adapted for use in an infringement of [the] patent"; a component that is either "a staple article" or "a commodity of commerce suitable for substantial noninfringing use" is excluded from the protection under this provision. See supra Section 3.4.

${ }^{188}$ Holbrook, Territoriality, Chapter I, note 5, 717; see also Honeywell Intern. Inc. v. Acer America Corp., 655 F.Supp.2d 650 (E.D.Tex. 2009) ("[U]nder the current state of the law, the scope of section $27 \mathrm{I}$ (b) can extend to extra-territorial activities." Id., 660); Wing Shing Products (BVI), Ltd. v. Simatelex Manufactory Co., Ltd., 479 F.Supp.2d 388, 410 (S.D.N.Y. 2007).

${ }^{189}$ See, e.g., the decision allowing discovery against a Taiwanese defendant concerning the defendant's activities outside the United States in Honeywell Intern. Inc. v. Acer America Corp., 655 F.Supp.2d 650 (E.D.Tex. 2009).

${ }^{190} 35$ U.S.C. $\$ 271(\mathrm{c})$.

${ }^{191}$ Transocean Offshore Deepwater Drilling, Inc. v. Maersk Contractors USA, Inc., 617 F.3d I296 (Fed. Cir. 2010).

${ }^{192}$ See supra Section 3.3 for a discussion of the territorial extent of the "offer to sell."
} 
As discussed earlier in Section 3.3, the current interpretation in the United States of an infringing "offer to sell" in Section 27I(a) rendered the "offer to sell" de facto an act of indirect infringement. Although it may appear from the statutory text that an offer to sell should be an act of direct infringement, as are the other acts enumerated in Section $27 \mathrm{I}(\mathrm{a})$, by making the place of the intended sale the decisive element of the analysis ${ }^{193}$ the U.S. Court of Appeals for the Federal Circuit placed the act of offer to sell in the category of indirect infringement, which requires a related act of direct infringement (the act of sale) in the United States. This is not the first time that a court has interpreted an act of infringement as an act of indirect infringement notwithstanding the fact that Congress placed the act among the acts of direct infringements. In Subafilms, Ltd. v. MGM-Pathe Communications Co. ${ }^{194}$ the U.S. Court of Appeals for the Ninth Circuit explained that the legislative addition of the acts of "authorization" to the exclusive rights under the U.S. Copyright Act did not result in the creation of new grounds for finding direct infringement but only ratified the existing grounds of indirect liability. ${ }^{195}$ Under the U.S. Court of Appeals for the Federal Circuit's interpretation of "offer to sell" it also appears that the addition of the act of "offer to sell" to the Patent Act only reiterated a form of indirect infringement that in most cases could probably be covered by the inducement provision of Section $27 \mathrm{I}(\mathrm{b}) \cdot{ }^{196}$

The provision on indirect infringement that was inserted into the German Patent Act in $1980^{197}$ is also limited to acts committed "within the territory of the application of the Act," i.e., in Germany. ${ }^{198}$ Under Article ro, a contributory infringer is one who offers to sell or supplies a component "related to an essential element of the invention" "for use of the invention in Germany." ${ }^{199}$ For an indirect infringement to

\footnotetext{
${ }^{193}$ See supra note 129.

${ }^{194}$ Subafilms, Ltd. v. MGM-Pathe Communications Co., 24 F.3d 1088 (1994).

${ }^{195}$ Id., 1093 .

${ }^{196}$ Inducement could not have been found in Transocean Offshore because there the alleged infringer did not induce infringement; instead, the alleged infringer reserved "the option to alter the rig to avoid infringement." Transocean Offshore Deepwater Drilling, Inc. v. Maersk Contractors USA, Inc., 617 F.3d 1296, 1308 (Fed. Cir. 2010).

${ }^{197}$ The provision was modeled after Article 30 of the 1975 Community Patent Convention. Convention for the European Patent for the Common Market, 1976 O.J. (L 17) r. Cyrill P. Rigamonti, Theorie und Praxis der mittelbaren Patentverletzung, 2009 Mitteilungen der deutschen Patentanwälte 57, 58.

${ }^{198}$ The condition of the so-called "double connection" requires that I) the offer or the supply be directed at Germany, and 2) the expected use following the offer or the supply (the acts of direct infringement) also occur in Germany. See, e.g., Luftdruck-Kontrollvorrichtung, Landgericht Mannheim, 7 O 412/03, June 25, 2004, 5

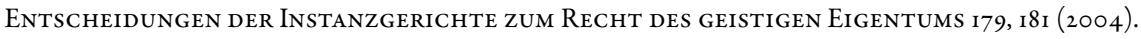

${ }^{199}$ Article 8(4) of the Patent Act of Dec. 16, 1980; Article Io(I) of the current Patent Act. For a history of the concept of "mittelbare Patentverletzung" - or "indirect patent infringement"-in Germany, see Jan Busche, Mittelbare Patentverletzung - zu den dogmatischen Grundlagen eines Rechtsinstituts, 2009 GRUR 236, 237-38.
} 
be found under this provision, the indirect infringer must have known —or it had to be obvious to the indirect infringer from the circumstances-that the components "are suitable and intended to be employed in the use of the invention." ${ }^{200}$ Components "commonly available on the market" are generally excluded from the provision on indirect infringement, with one exception: an indirect infringement will occur when someone offers to sell or supplies "components commonly available on the market" that pertain to a patented process when the infringer induces the purchaser or the entity supplied to either use the components to run the patented process, or offer the components for use in the patented process. ${ }^{201}$

Although acts of indirect infringement committed outside of Germany are excluded from Article io, this exclusion does not preclude patent holders from using the provision against someone involved in utilizing their inventions abroad. In Funkubr $I I^{202}$ the Bundesgerichtshof explained that a German company may be liable under the provision when it supplies a component from Germany abroad; the court reiterated that " $[\mathrm{a}] \mathrm{n}$ indirect patent infringement can [...] be committed by supplying means that relate to an essential element of the invention abroad if they are to contribute to the manufacture there of a product according to the invention which is intended for supply to Germany." 203 The court noted that while normally an act of supplying abroad would not trigger the application of the provision on contributory infringement, the provision does apply in cases where the ultimate goal is the use of the invention in Germany. ${ }^{204}$

While Article Io may affect the utilization of an invention abroad only when the foreign utilization is associated with an act of indirect infringement in Germany,

On the concept of "essential components," see, e.g., Thomas Kühnen \& Eva Geschke, Die Durchsetzung von Patenten in Der Praxis 84-86 (2008); Michael Nieder, Die mittelbare Patentverletzung - eine Bestandsaufnabme, 2006 GRUR 977, 977-78.

200 "Pursuant to Sec. Io of the Patent Act the effect of the patent is that, without the patent holder's consent, any third party is prohibited from offering or supplying within the territory of the application of the Patent Act any means related to an essential element of the invention to persons [other than the persons entitled to use the patented invention in Germany], provided that the third party knows or it is obvious in the light of the circumstances that these means are capable of being applied and intended to be applied for the use of the inventions." Funkubr II, supra note I80.

${ }^{201}$ Articles 9(2) and Io(2).

${ }^{202}$ Funkubr II, supra note 180.

${ }^{203} I d$. "[I] f the delivery is made in order for use to be made of the invention in Germany, this is precisely the threat to the rightholder's domestic patent rights that [Article] Io of the Act is intended to prevent." Id. The issue in this case was whether a German supplier had standing to sue the patent holder for sending unjustified cease and desist letters to a distributor when the patent was allegedly infringed by a foreign company that made the product at issue abroad from an essential component delivered by the German supplier. The product was then supplied to Germany and the patent holder sent the letter to the distributor.

${ }^{204}$ Funkubr II, supra note I80. 
a much wider net is cast for activities abroad through the doctrines of participating and aiding and abetting; ${ }^{205}$ these doctrines have allowed German courts to reach persons involved in the utilization of inventions abroad. In Funkubr ${ }^{206}$ a Dutch company, aware of the German patent covering a certain device in Germany, supplied devices to another Dutch company, which, as the supplier knew, supplied them into Germany. The court found infringement by the first Dutch company because that company "knew of the patent and knew of the country of destination and therefore willingly and willfully helped to cause the domestic distribution." ${ }^{207}$ Similarly, the Düsseldorf Landgericht decided in Sitz-Stützelement ${ }^{208}$ that an Austrian manufacturer infringed when it supplied a device patented in Germany into the United Kingdom where the device was installed into cars that were thereafter distributed in several countries, including Germany. The court emphasized that the Austrian manufacturer was liable because it knew of the patent and of the country of destination. In Herkranzgefäß-Dilatationskatheter ${ }^{209}$ the Düsseldorf Landgericht found an Israeli manufacturer liable when the manufacturer supplied catheters to a dealer in the United States who then supplied them to various countries, including Germany, and offered them on the Internet to German customers. What was again dispositive in the decision was that the Israeli company knew of the German patent and of the U.S. supplier's intent to offer and distribute the device in Germany. The Mannheim Landgericht dealt with a similar case, Kondensator für Klimaanlage, ${ }^{210}$ in the context of personal jurisdiction. The court decided that an Austrian defendant could have infringed a patent when supplying devices to car manufacturers in Italy (Alfa Romeo), and France and Spain (Citroen); some of the cars with the devices installed were shipped to Germany. ${ }^{211}$

\footnotetext{
${ }^{205}$ Civil Code, $\$ 830$.

${ }^{206}$ Funkuhr, Bundesgerichtshof, X ZR 36/or, Feb. 26, 2002, 2002 GRUR 599.

${ }^{207}$ Erhard Keller, Patentverletzungen durch Handlungen im patentfreien Ausland, in Festschrift FÜr EIKE Ullmann 449, 454 (Hans-Juergen Ahrens, Joachim Bornkamm, \& Hans Peter Kunz-Hallstein eds., 2006). ${ }^{208}$ Sitz-Stützelement, Landgericht Düsseldorf, 4a O 395/02, Nov. 18, 2003; see also Keller, supra note 207, 457.

${ }^{209}$ Herkranzgefäß-Dilatationskatheter, Landgericht Düsseldorf, $4 \mathrm{a}$ O 311/O2, Oct. 28, 2003, 3 EnTsCheIdUngen DeR InStanzgerichte zUm Recht Des Geistigen Eigentums 174 (2002); see also Keller, supra note 207, 456-57.

${ }^{210}$ Kondensatore für Klimaanlage, Landgericht Mannheim, 7 O 506/04, Aug. 26, 2005, 6 EnTsCheidungen Der Instanzgerichte zUm Recht Des geistigen Eigentums 9 (2005). The court pointed to a Swiss Bundesgericht decision in Testkassetten in which the Swiss court confirmed that "one who participates in an infringement [in the protecting country may be] held civilly liable when the participant acts solely abroad but from there caused or supported patent infringement in [the protecting country]. [...] The required connection [to the protecting country] is created by the knowing and willful support of [the result in the protecting country]." Id., I2.

${ }^{211}$ See also Kombi-Sicherheitsnetz, Landgericht Düsseldorf, 4a O 56/09, July 13, 2010.
} 
The German law thus reaches the kind of infringements that Nicholas Oros aptly termed "infringement twice removed"; ${ }^{212}$ these infringements appear to be reachable also under U.S. law. For example, in the United States in Crystal Semiconductor Corp. v. TriTech Microelectronics Intern., Inc., ${ }^{213}$ a foreign manufacturer was found indirectly liable when the manufacturer dealt solely with another company that supplied infringing products into the United States; the foreign defendant manufacturer TriTech sold chips to OPTi, which then sold them into the United States. The U.S. Court of Appeals for the Federal Circuit found that "TriTech's acts in connection with selling its chip to OPTi [...] constitute[d] active inducement under 35 U.S.C. \$27I (b)."214

The patent laws of Germany and the United States overlap in scope with respect to acts committed abroad that contribute to an infringement in Germany or the United States as the protecting country. The acts prohibited by the U.S. Patent Act as acts of inducement are covered as acts of indirect infringement under the German Civil Code provision for participating in or aiding and abetting a direct infringement. Additionally, under the recent interpretation by the U.S. Court of Appeals for the Federal Circuit, ${ }^{215}$ "offers to sell" are treated as acts of indirect infringement because offers made outside the United States for sale of a patented product (or a product made by a patented process) in the United States will be actionable under the "offer to sell" provisions of the U.S. Patent Act. ${ }^{216}$

\subsection{Acts in Multiple Locations}

One of the ways in which acts committed outside the protecting country may be drawn into the scope of the patent law of the protecting country is when a finding is made that the same act has been committed in multiple locations, one of which is in the protecting country. ${ }^{217}$ Localization of an act in a certain place may be important

\footnotetext{
${ }^{212}$ Nicholas Oros, Infringement Twice Removed: Inducement of Patent Infringement for Overseas Manufacture of Infringing Products Imported by Another, ro Computer L. Rev. \& TeCH J. I63 (2006).

${ }^{213}$ Crystal Semiconductor Corp. v. TriTech Microelectronics Intern., Inc., 246 F.3d 1336 (Fed. Cir. 200I).

${ }^{214} I d$., I35I.

${ }^{215}$ Transocean Offshore Deepwater Drilling, Inc. v. Maersk Contractors USA, Inc., 617 F.3d I296 (Fed. Cir. 2010).

${ }^{216}$ See supra Section 3.3 for a discussion of the infringing "offer to sell."

${ }^{217}$ Generally on ambiguity of the place of an infringing act, see Edward Geller, International Intellectual Property, Conflicts of Laws and Internet Remedies, 22 EUR. INTELL. Prop. REv. I25, 126 ff. (2000). An appropriate characterization of the acts may also be a problem, although perhaps less so in patent infringement cases than in other cases. Id., 126.
} 
for establishing personal jurisdiction over the infringer; in cases where an infringer's domicile is outside the protecting country it is often necessary to base personal jurisdiction on tortious acts occurring in the protecting country. ${ }^{218}$ Furthermore, even if courts have personal jurisdiction over an alleged infringer based on other grounds, such as the domicile of the alleged infringer, if the courts of a country do not consider patent infringement to be a transitory cause of action, and they therefore refuse to adjudicate infringements under foreign patent laws, those courts will not adjudicate infringements at all unless the localization of the act places the act within the scope of the country's patent law. Therefore, the proper localization of an act is of crucial importance when patent holders hold patents in only one country or a limited number of countries and they must deal with an infringement that originates in a country where their invention is not protected. In such cases the localization in the protecting country will determine whether an infringement can be found at all, and therefore whether any remedies are available.

Although regular choice of law provisions for torts should provide sufficient guidance for localization of acts of patent infringement, ${ }^{219}$ the limited territorial scope of patent law requires that acts be examined in the context of the potential applicability of the patent law of the particular country. ${ }^{220}$ For instance, choice of law provisions in the 2007 Rome II Regulation, ${ }^{221}$ which apply in the countries that are members of the European Union, including Germany, ${ }^{222}$ point in cases of torts in general to the "law of the country in which the damage occurs." 223 However, the special provision on infringement of intellectual property rights in Article 8.I of the Regulation, which is designed to comply with "the universally acknowledged principle of the lex loci protectionis," ${ }^{224}$ calls for application in such infringement cases of

\footnotetext{
${ }^{218}$ E.g., Restatement (Second) of Conflict of Laws, $\$_{3} 6, \$_{37}, \$ 49$, and $\$ 50$; Brussels I Regulation, Chapter 2 , note 25, Article 5(3). See also ALI Principles, Chapter 2, note 123, Section 204.

${ }^{219}$ In the United States almost half of U.S. states apply the law of the state with the "most significant relationship" under Restatement (Second) of Conflict of Laws \$145 (1971); ten states apply the traditional lex loci delicti rule. See Symeon C. Symeonides, Choice of Law in the American Courts in 2008: Twenty-Second Annual Survey, 57 Ам. J. Сомp. L. 269, 279 (2009).

${ }^{220}$ For a discussion of this phenomenon see Alexander Peukert, Territoriality and Extraterritoriality in Intellectual Property Law, in Beyond Territoriality: Transnational Legal Authority in the Age of Globalization (Gunther Handl \& Joachim Zekoll eds., 20II).

${ }^{221}$ Regulation (EC) No 864/2007 of the European Parliament and of the Council of II July 2007 on the law applicable to noncontractual obligations (Rome II), 2007 O.J. (L 199) 40 ("Rome II Regulation").

${ }^{222}$ Prior to the effective date of the Rome II Regulation (Jan. II, 2009) the German choice of law provisions concerning noncontractual obligations were in Articles 27-37 of the Introductory Act to the Civil Code (Einführungsgesetzes zum Bürgerlichen Gesetzbuche).

${ }^{223}$ Rome II Regulation, supra note 22I, Article 4(I).

${ }^{224} I d$., Recital 26.
} 
the "law of the country for which protection is claimed." To ascertain whether protection may be claimed for Germany, a determination is required as to whether the acts at issue may be viewed as acts that infringe a patent under German patent law; the territorial scope of the German Patent Act, as interpreted by German courts, will determine how far the Act extends as applicable law. ${ }^{225}$

The importance of localization may be demonstrated by an example using a sale. In the United States, if a "sale" occurs "within the United States"226 it is infringing, and therefore it is essential to know what facts are sufficient for courts to deem certain acts to fall within the scope of the term "sale." A sale may be defined in either legal or physical terms; as the U.S. Court of Appeals for the Federal Circuit has noted, legal terms concentrate only on "the single point at which some legally operative act took place, such as the place where the sales transaction would be deemed to have occurred as a matter of commercial law."227 Physical terms, however, offer courts the opportunity to view various facts as determinative of the location of the sale; for instance, "the location of the seller and the buyer" 228 or "the points along the shipment route." ${ }^{229}$ U.S. and German courts both look beyond purely legal terms and consider physical terms when localizing a sale. ${ }^{230}$

Some sellers try to protect themselves from the reach of the patent law of a particular country by selling goods from abroad and shipping them to customers in the protecting country "free on board." ${ }^{231}$ A shipment "free on board" means that the title to the goods is transferred when the seller delivers the goods to a carrier; therefore, sellers have argued that it should be at this point that the act of sale occurs, because this is where sellers no longer have responsibility for the goods. U.S. courts, however, do not view the issue of the shift in liability for goods as dispositive of the issue of the place of sale for the purposes of the U.S. Patent Act. In MEMCElectronic Materials, Inc. v. Mitsubishi Materials Silicon Corp. ${ }^{232}$ the U.S. Court of Appeals for

\footnotetext{
${ }^{225}$ This is different from torts in general, which concern rights that have no explicit territorial limits and for which the forum's choice of law provisions set the territorial reach.

${ }^{226} 35$ U.S.C. $\$ 27 \mathrm{I}(\mathrm{a}),(\mathrm{b})$ and $(\mathrm{g})$.

${ }^{227}$ North American Philips Corp. v. American Vending Sales, Inc., 35 F.3d 1576, 1579 (Fed. Cir. 1994).

${ }^{228}$ Id. See also Litecubes, LLC v. Northern Light Products, Inc., 523 F.3d I353, 1369 (Fed. Cir. 2008); cert. denied on Nov. I0, 2008.

${ }^{229} \mathrm{Id}$.

${ }^{230}$ As noted supra in Section 3.3, while both U.S. and German courts have adopted a liberal approach to the interpretation of a "sale" (by looking beyond pure contract law terms), U.S. courts have adopted a rigid approach to the interpretation of an "offer to sell" by requiring that acts fall into the contract law definition of an offer for the acts to constitute an infringing offer to sell under the U.S. Patent Act.

${ }^{231}$ For a definition of the term "free on board," see Incoterms 2000 by the International Chamber of Commerce, available at http://www.iccwbo.org/incoterms/preambles/pdf/FOB.pdf (last visited Sept. 2, 20II).

${ }^{232}$ MEMC Electronic Materials, Inc. v. Mitsubishi Materials Silicon Corp., 420 F.3d 1369 (Fed. Cir. 2005).
} 
the Federal Circuit stated that a sale is not necessarily precluded from occurring in the forum "simply because an article is delivered 'free on board' outside of the forum"; 233 according to the court, other factors, such as places of contracting and performance may be more important when a sale needs to be localized. ${ }^{234}$

Localization may also be difficult in cases involving use, particularly if the infringing use concerns patented inventions that consist of various parts-either steps in cases of process patents, or components in cases of system patents. The localization is complicated when individual components of the system are used or steps in the process are performed in different countries; the U.S. case NTP $v$. Research in Motion $^{235}$ exemplified these problems. The case concerned a technology that enables receipt of e-mails on mobile devices through a wireless network; the extraterritorial component was a relay located in Canada through which the e-mails were routed. ${ }^{236}$ The defendant argued that U.S. patent law could not be applied because it does not extend extraterritorially and thus cannot cover acts committed in Canada. ${ }^{237}$ The U.S. Court of Appeals for the Federal Circuit relied on an earlier decision of the U.S. Court of Claims in Decca Ltd. v. United States ${ }^{238}$ to conclude that the use of a system may be infringing under U.S. patent law even if a component of the system is located abroad; however, it suggested that a different analysis must be performed for method claims that make up the processes covered by a patent. ${ }^{239}$ The court localized the use of the system as "the place where control of the system is exercised and beneficial use of the system obtained," 240 which was the United States. However, the use of the process could not be localized in the United States; the court explained that for a process to be infringed through use, each of the steps of the process has to be performed, and therefore a process cannot be infringed in the United States through use unless all of the steps are performed in the United States. ${ }^{241}$

${ }^{233}$ Id., 1377 .

${ }^{234}$ See supra Section 3.2 for examples of German cases. See also Chapter 4 , Section 4.2.I, for a discussion of the case Litecubes, LLC v. Northern Light Products, Inc., 523 F.3d 1353 (Fed. Cir. 2008).

${ }^{235}$ NTP v. Research in Motion, 418 F.3d 1282 (Fed. Cir. 2005), cert. denied.

${ }^{236} I d$., $\mathrm{I} 289-90$.

${ }^{237} \mathrm{Id}$., $\mathrm{1} 3 \mathrm{I} 3$.

${ }^{238}$ Decca Ltd. v. United States, 210 Ct.Cl. 546 (Ct. Cl. 1976).

239 "The term 'process' means process, art, or method, and includes a new use of a known process, machine, manufacture, composition of matter, or material.” 35 U.S.C. \$roo(b).

${ }^{240}$ NTP v. Research in Motion, 418 F.3d I282, I3I7 (Fed. Cir. 2005), cert. denied.

${ }^{241}$ Id., 1317-18. In Cardiac Pacemakers the U.S. Court of Appeals for the Federal Circuit held that process patents cannot be infringed through acts under 35 U.S.C. \$27 I (f). Cardiac Pacemakers, Inc. v. St. Jude Medical, Inc., 576 F.3d 1348, 1365 (Fed. Cir. 2009). On the so-called "divided infringement claims," see Mark A. Lemley, David O'Brien, Ryan M. Kent, Ashok Ramani, \& Robert Van Nest, Divided Infringement Claims, 33 AIPLA Q.J. 255 (2005); Melissa Feeney Wasserman, Divided Infringement: Expanding the Extraterritorial Scope of 
The question of whether a process patent can be infringed in one country when some of the steps of the process are performed in different countries was also addressed by German courts. In 2007 the Bundesgerichtshof decided a case of infringement of a "method to control the elevation of the temperature of electrically heated parts" ${ }^{242}$ in Rohrschweissverfahren; ${ }^{243}$ in that case the initial steps of the process were performed in Switzerland and the subsequent steps were performed in Germany. ${ }^{244}$ The court held that the patent was infringed in Germany through the final steps of the process. ${ }^{245} \mathrm{~A}$ fact situation that raised a mirror-image question appeared in 2009 before the Düsseldorf Oberlandesgericht; in Prepaid-Karten II the initial steps of a process were performed in Germany and the subsequent steps in other countries. ${ }^{246}$ The court held that the "method of processing telephone cards" at issue was infringed in Germany "notwithstanding the undeniable cross-border aspect." ${ }^{247}$ The court emphasized that in accordance with the principle of territoriality, acts that occur entirely abroad cannot infringe a German patent; however, the result will be different if at least a portion of an act occurs in Germany. ${ }^{248}$ Therefore, a process patent will be infringed in Germany if the infringer performs some of the necessary steps in Germany, as long as the rest of the steps that are performed abroad may be attributed to the infringer in Germany. ${ }^{249}$

Localization may also be challenging when infringing acts are committed on the Internet. ${ }^{250}$ In Germany courts view advertisements on the Internet as infringing

Patent Law, 82 N.Y.U. L. Rev. 28I (2007). The case of NTP v. Research in Motion settled and was dismissed without prejudice in March 2006. NTP v. Research in Motion, U.S. District Court for the Eastern District of Virginia, case no. 3:0I-cv-00767-JRS, order, docket document no. 464, March 3, 2006.

${ }^{242}$ European patent EP 0272978 (AI).

${ }^{243}$ Rohrschweissverfahren, Bundesgerichtshof, X ZR I13/04, Feb. 24, 2007.

${ }^{244}$ Rohrschweissverfahren, Oberlandesgericht Düsseldorf, 2 U I8/03, June 24, 2004.

${ }^{245}$ Rohrschweissverfahren, Bundesgerichtshof, X ZR I13/04, Feb. 24, 2007

${ }^{246}$ Prepaid-Karten II, Oberlandesgericht Düsseldorf, 2 U 5I/08, Dec. I0, 2009.

${ }^{247} \mathrm{Id}$.

${ }^{248} I d$.

${ }^{249} \mathrm{Id}$. See also Landgericht Düsseldorf, $4 \mathrm{a} \mathrm{O} 235 / 06$, Aug. 14, 2007. The decision concerned a patent on a "method for making a perfected medical model on the basis of digital image information of a part of the body" EP $0756735(\mathrm{BI})$. The defendants had one of the steps of the method performed in Sweden or the United States, but the court held that this fact did not preclude a finding of infringement of the method in Germany because "[f] or the cause of action of a use of a process it suffices when one or more steps are performed in [Germany] and others abroad, when the other necessary steps that were accomplished abroad can be attributed to the actor in [Germany]." Id., para. 117 .

${ }^{250} \mathrm{As}$ Edward Geller noted in an article from 2000, "[ $t$ ]he ambiguity [of the place of infringing acts] arises out of the increasing efficacy of the media and technology." Geller, International, supra note 217, 126. The problems of enforcing patents on the Internet were thoroughly discussed as early as 1993 by Dan Burk, supra note 7. 
offers to sell; for instance, in Soblen für Sportschube ${ }^{251}$ the Düsseldorf Landgericht considered as infringing an offer to sell when a U.S. manufacturer advertised a product on the Internet together with a list of German distributors. In Einrichtung zur zentralen Notlichtversorgung ${ }^{252}$ the court found an offer to be localized in Germany when the Internet website was written in German. The defendant argued that it did not target distributors in Germany and that it exported its goods only to customers outside of Germany, but the court pointed out that there was no disclaimer on the website that would inform potential purchasers that the defendant would not supply goods to Germany for use in Germany. ${ }^{253}$

\subsection{Limits on the Protection of an Invention outside the Protecting Country}

The mechanisms described in this chapter provide important tools for patentees who, for whatever reason, cannot obtain patent protection in all countries of the world, or simply in a country where their invention is exploited. The mechanisms can also serve as alternatives to the parallel enforcement of multiple national patents when it is impossible to litigate the infringement of the patents in some particular country (because the patent infringements are not considered transitory causes of action or because the act of state doctrine prevents courts from deciding cases concerning foreign patents) ${ }^{254}$ or the litigation is unlikely to succeed in that country (for example, if raising invalidity causes a removal or stay of the proceedings). ${ }^{255}$ Although the mechanisms are often used as alternatives to multinational litigation, their existence cannot be explained only as a reaction to the high costs and complications of litigating in multiple countries simultaneously; ${ }^{256}$ even if ways are found to make enforcement of parallel patents less complicated and costly, as discussed in Chapter 2, these mechanisms would still be needed by inventors who lack protection in countries where their invention is utilized, or who want to benefit from the

\footnotetext{
${ }^{251}$ Soblen für Sportschuhe, Landgericht Düsseldorf, 4a O 33/or, Feb. 5, 2002.

${ }^{252}$ Einrichtung zur zentralen Notlichtversorgung, Landgericht Düsseldorf, 4a O 78/o8, Mar. 26, 2009.

${ }^{253} \mathrm{On}$ the role of a disclaimer, see Arzneimittelwerbung im Internet, Bundesgerichtshof, I ZR 24/03, Mar. 30 , 2006, 2006 GRUR 513, 515.

${ }^{254}$ See Chapter 2, Section 2.I.6, for a discussion of approaches of courts in the United States and Germany to deciding cases involving foreign patents.

${ }^{255}$ See, e.g., Chapter 2, Sections 2.I.I and 2.I.2, for the situation in the European Union under the Brussels regime.

${ }^{256}$ Kendra Robins, Extraterritorial Patent Enforcement and Multinational Patent Litigation: Proposed Guidelines for U.S. Courts, 93 VA. L. REv. 1259, 1302 (2007). Kendra Robins suggests that "U.S. courts should look to multinational litigation before seeking to enforce U.S. patents extraterritorially." Id.
} 
substantive or procedural advantages of the legal system of a particular protecting country.

This chapter shows that U.S. and German patent laws reach the exploitation of inventions beyond their countries' borders; in most respects the territorial reach of the laws is comparable, and in certain cases the extraterritorial reach of German patent law appears to be greater than that of U.S. law. ${ }^{257}$ In most cases both laws achieve the same results, notwithstanding the differences in their statutory language; for example, despite their differing approaches to the issue of components, U.S. and German laws both seem to arrive at similar results with regard to components made domestically or offered for sale domestically for the purpose of assembly abroad.

In at least two scenarios the German approach reaches further than U.S. law: the offer to sell and the direct infringement of process patents. In Germany it has been accepted for decades that an offer to sell that is made in Germany is infringing even if the resulting sale occurs abroad, and in Germany the concept of an offer to sell includes any act that might be considered an offer to sell in an economic sense-no formal offer to sell as defined by contract law is necessary. In the United States, the U.S. Court of Appeals for the Federal Circuit has interpreted offers to sell as infringing only if they concern sales that occur or are intended to occur in the United States, and has construed an offer to sell strictly according to contract law terms. The German approach also appears to extend further in cases of cross-border infringements of process patents. In the United States under NTP a process patent cannot be infringed unless all of the steps of the process are performed in the United States; however, recent German decisions show that German courts have applied German patent law to a process even when the individual steps of the process are performed in multiple countries. ${ }^{258}$

It is remarkable that despite the similarities of U.S. and German law in their territorial reach, German law has not been subjected to the high level of criticism that is aimed at the excessive extraterritoriality of U.S. law; although not absent from the German literature, ${ }^{259}$ criticism of the German approach is much less frequent than is

\footnotetext{
${ }^{257}$ Naturally, the fact that patent law doctrines in one country reach further than the doctrines in another country does not necessarily mean that right holders are in a better position to enforce their rights under the law of the former rather than under the law of the latter; there are other factors that influence a patent holder's success in enforcing his rights, such as procedural rules and alternatives to enforcement through litigation, such as border enforcement measures.

${ }^{258}$ See supra Section 3.6 for a discussion of infringements of process patents by acts in multiple countries.

${ }^{259}$ See, for instance, the criticism by Jens Adolphsen of the decision by the Düsseldorf Landgericht in Rohrverzweigung. The Düsseldorf Landgericht found that a Czech manufacturer could be held liable for infringement of a German patent because the manufacturer supplied a product to a German purchaser knowing that the purchaser intended to resell the product in Germany. Rohrverzweigung, 4 O 438/99, Landgericht Düsseldorf, Nov. 7, 2000, I ENTSCHEIDUngen DER InSTANZGerichte Zum Recht Des Geistigen
} 
criticism in the literature discussing the situation in the United States. ${ }^{260}$ One can only speculate on the origins of the more frequent criticism of the U.S. approach. It is undeniable that certain procedural differences mean that the U.S. system in general takes a more aggressive approach toward enforcement than the German litigation system does; examples are the availability in the United States of discovery and jury trials in patent infringement cases.

Two additional differences between the systems may explain the differing levels of criticism; the first is historical and the second is statutory. First, since the end of the nineteenth century, German law has developed strong tools for holders of German patents to protect their inventions; for instance, an infringing offer to sell was included in German patent law as an independent tort as early as 1877 and was applied even when offers involved foreign sales. The longer and more gradual German law tradition of reaching activities abroad may explain why the extraterritorial reach of German patent law is not as surprising to commentators as is the reach of U.S. patent law.

The second difference between the U.S. and German systems that may underlie the perception that the extraterritoriality of U.S. patent law has an excessive reach is an optical illusion resulting from the different statutory language governing certain acts of infringement. Compared to the U.S. Patent Act provisions on infringement in Section 271, the German Patent Act is very brief in describing what constitutes an infringement of a German patent; in fact, the general provisions on infringement appear only in the relatively short Article 9 and Article ro of the Patent Act. However, what is more important is that the German Patent Act does not mention any activity outside Germany; the U.S. Patent Act, by contrast, explicitly states that it targets activities abroad in Section $27 \mathrm{I}(\mathrm{f})$ (which concerns the supply of components in or from the United States) and Section $27 \mathrm{I}(\mathrm{g})$ (which applies to products made outside the United States by processes that are patented in the United States). ${ }^{261}$

EIGENTUMS I54 (2000). The court emphasized that it was dispositive that the machines were from the beginning intended to be sold in Germany. Adolphsen criticizes the decision because of the finding of jurisdiction and insists that "the acts outside the protecting country [such as the labeling of products in the language of the protecting country, or the long-term contractual relationship with an importer in the protecting country] do not support jurisdiction of the court of the protecting country because these acts do not yet have the effect of infringement of the protected rights." Adolphsen, EuropäIsChes, Chapter 2, note 47, 163 .

${ }^{260}$ E.g., Schroeder, supra note 8, 77-78; Holbrook, Extraterritoriality, supra note 7, 2127-28; Bradley, supra note 7, 584; Cameron Hutchison \& Moin A. Yahya, Infringement \& the International Reach of U.S. Patent Law, 17 FED. Cir. B.J. 24I, 255 (2008); Brief for Amici Curiae Law Professors in Support of the Appellee, Jan K. Voda, M.D. v. Cordis Corporation, No. 05-1238 (Fed. Cir. July 29, 2005), 3.

${ }^{261}$ Dariush Keyhani, U.S. Patent Law and Extraterritorial Reach, 7 Tul. J. TeCH. \& InTELl. Prop. 5i (2005) (Noting that " $[\mathrm{i}] \mathrm{n}$ recent years, the U.S. legislature and courts have expanded the extraterritorial scope of U.S. law to accommodate the growing economic importance of intellectual property." Id., 52 .). 
These explicit extraterritorial ambitions in the U.S. Patent Act make it appear as though U.S. law attempts to reach further than the laws of other countries. Despite the general perception that the laws of civil law countries are more detailed and leave less discretion to their courts on interpretation than the laws of common law countries, on the issue of infringing acts, the German Patent Act has remained succinct, and German courts have interpreted its provisions on infringement in a manner that has avoided the need for substantial legislative changes like those that have been introduced into the U.S. Patent Act. ${ }^{262}$

It has been suggested that allowing patent laws to reach activities outside the protecting country has negative effects; in addition to expressing concerns over possible injury to international comity, some critics point out that the use of patent laws against conduct abroad exposes businesses to uncertainty about the legality of their activities $^{263}$ and thereby hinders the development of new businesses. However, commentators understand that many patent holders need to "stretch" the patent laws of a protecting country beyond its borders because they do not hold patents elsewhere. To reconcile the two types of interests, mitigating approaches have been proposed that would limit the application of the patent laws of one country to avoid offending other countries in their perceptions of what should be protected. For example, Timothy Holbrook proposed a system in which proof of infringement of a U.S. patent through conduct abroad would require proof "that the infringer would also infringe under the laws of the foreign country."264

Although they are commendable for addressing the patent policies of foreign countries and attempting harmonious international cooperation, these mitigating approaches might not be necessary. The application of any law is limited by a country's ability to enforce it; if enforcement is not feasible, any "application" of that law (meaning judicial proceedings leading to a judgment on the merits) is a useless exercise. If a country decides to adopt laws that will govern conduct abroad, the scope of those laws will be limited de facto by the country's ability to enforce its laws against those acting abroad, and the willingness of other countries to enforce the laws against those who are out of reach of the protecting country's own enforcement power. As long as an infringer is domiciled in the protecting country or has assets there that can be reached to enforce a judgment of a court of the protecting country applying its laws, the opinion of other countries about the extent of the reach of those laws is irrelevant; enforcement in the protecting country will be possible. However, once

\footnotetext{
${ }^{262}$ See also Moufang, supra note 163, 617.

${ }^{263}$ Hutchison \& Yahya, supra note 260, 255.

${ }^{264}$ Holbrook, Extraterritoriality, supra note 7, 2120. See also Robins, supra note 256, 1309-14.
} 
the infringer is not domiciled or has no assets in the protecting country, patent holders must take the protecting country's judgment to the country where the infringer is domiciled or where his assets are located and seek recognition and enforcement of the judgment in that country. Refusals by foreign countries to recognize the decisions by courts of protecting countries create a natural boundary to the extraterritorial application of patent laws.

The next chapter explores the potential enforcement difficulties that circumscribe the boundaries of patent laws and offers a quantitative view of the phenomena in current U.S. patent litigation. 